Article

\title{
Genotypic and Phenotypic Characterization of Incompatibility Group FIB Positive Salmonella enterica Serovar Typhimurium Isolates from Food Animal Sources
}

\author{
Nesreen H. Aljahdali ${ }^{1,2}{ }^{,}$Bijay K. Khajanchi ${ }^{1}$, Kennedi Weston ${ }^{1,3}{ }^{\text {, Joanna Deck }}{ }^{1}$, Justin Cox ${ }^{1}$, \\ Ruby Singh ${ }^{4}$, Jeffrey Gilbert ${ }^{4}$, Yasser M. Sanad ${ }^{1,3,5}$, Jing Han ${ }^{1}$, Rajesh Nayak ${ }^{1}$ and \\ Steven L. Foley ${ }^{1, *}$ \\ 1 Division of Microbiology, U.S. Food and Drug Administration, National Center for Toxicological Research, \\ Jefferson, AR 72079, USA; nesreen.aljahdali@fda.hhs.gov (N.H.A.); bijay.khajanchi@fda.hhs.gov (B.K.K.); \\ kennedi.weston@fda.gov (K.W.); joanna8deck@icloud.com (J.D.); justincox025@gmail.com (J.C.); \\ sanady@uapb.edu (Y.M.S.); Jing.han1@fda.hhs.gov (J.H.); Rajesh.Nayak@fda.hhs.gov (R.N.) \\ 2 Biological Science Department, College of Science, King Abdul-Aziz University, Jeddah 21551, Saudi Arabia \\ Department of Agriculture, University of Arkansas at Pine Bluff, Pine Bluff, AR 71601, USA \\ 4 Office of New Animal Drug Evaluation, U.S. Food and Drug Administration, Center for Veterinary Medicine, \\ Rockville, MD 20855, USA; ruby.singh@fda.hhs.gov (R.S.); jeff.gilbert@fda.hhs.gov (J.G.) \\ 5 Department of Parasitology and Animal Diseases, Veterinary Research Division, National Research Centre, \\ Giza 12622, Egypt \\ * Correspondence: steven.foley@fda.hhs.gov; Tel.: +(870)-543-7547
}

Received: 15 September 2020; Accepted: 30 October 2020; Published: 4 November 2020

check for updates

\begin{abstract}
Salmonella enterica is one of the most common bacterial foodborne pathogens in the United States, causing illnesses that range from self-limiting gastroenteritis to more severe, life threatening invasive disease. Many Salmonella strains contain plasmids that carry virulence, antimicrobial resistance, and/or transfer genes which allow them to adapt to diverse environments, and these can include incompatibility group (Inc) FIB plasmids. This study was undertaken to evaluate the genomic and phenotypic characteristics of IncFIB-positive Salmonella enterica serovar Typhimurium isolates from food animal sources, to identify their plasmid content, assess antimicrobial resistance and virulence properties, and compare their genotypic isolates with more recently isolated $S$. Typhimurium isolates from food animal sources. Methods: We identified $71 \mathrm{~S}$. Typhimurium isolates that carried IncFIB plasmids. These isolates were subjected to whole genome sequencing and evaluated for bacteriocin production, antimicrobial susceptibility, the ability to transfer resistance plasmids, and a subset was evaluated for their ability to invade and persist in intestinal human epithelial cells. Results: Approximately 30\% of isolates $(n=21)$ displayed bacteriocin inhibition of Escherichia coli strain J53. Bioinformatic analyses using PlasmidFinder software confirmed that all isolates contained IncFIB plasmids along with multiple other plasmid replicon types. Comparative analyses showed that all strains carried multiple antimicrobial resistance genes and virulence factors including iron acquisition genes, such as iucABCD (75\%), iut $A(94 \%)$, sit $A B C D(76 \%)$ and sit $A B(100 \%)$. In 17 cases (71\%), IncFIB plasmids, along with other plasmid replicon types, were able to conjugally transfer antimicrobial resistance and virulence genes to the susceptible recipient strain. For ten strains, persistence cell counts $(27 \%)$ were noted to be significantly higher than invasion bacterial cell counts. When the genome sequences of the study isolates collected from 1998-2003 were compared to those published from subsequent years (2005-2018), overlapping genotypes were found, indicating the perseverance of IncFIB positive strains in food animal populations. This study confirms that IncFIB plasmids can play a potential role in disseminating antimicrobial resistance and virulence genes amongst bacteria from several food animal species.
\end{abstract}


Keywords: IncFIB plasmids; S. Typhimurium; SNP tree; conjugation; persistence; Caco-2 intestinal epithelial cells

\section{Introduction}

As one of the major causes of foodborne illnesses throughout the world, Salmonella enterica is estimated to cause approximately 1.35 million infections that result in 26,500 hospitalizations and 420 deaths per year in the United States alone [1,2]. The economic cost associated with these infections and death due to salmonellosis has been estimated to be up to 3.7 billion dollars each year due to loss of work, medical care, and quality of life lost [3,4]. Ninety-five percent of $S$. enterica infections are associated with consumption of contaminated food, and most often cause gastroenteritis that is characterized by stomach cramps, diarrhea, fever, and local infections [5]. S. enterica includes more than 2600 serovars, and the most predominant serovar causing human disease is S. enterica serovar Typhimurium, according to the Centers for Diseases Control and Prevention (CDC) [6,7]. $S$. Typhimurium is a potentially invasive bacterium causing illnesses ranging from mild gastroenteritis to enteric fever [8]. During the early stages of infection, $S$. Typhimurium survives the acid barrier of the stomach and invades the intestinal epithelium, facilitated by a Salmonella pathogenicity island (SPI) encoded type III secretion system (T3SS) $[9,10]$. S. Typhimurium, which contributes to significant morbidity and mortality worldwide, can carry plasmids that have been shown to harbor antimicrobial resistance and virulence genes [11,12].

Plasmids are often present in bacterial foodborne pathogens and typically provide traits to their host including antimicrobial resistance, virulence, and metabolism of rare substances $[13,14]$. Plasmids are generally not necessary for cell survival under normal conditions, but they allow pathogens to evolve and adapt to new environments [15]. Many antimicrobial resistance genes are encoded on transferable plasmids, which can facilitate the horizontal transfer of resistance genes via conjugation and provide dissemination of multidrug resistant (MDR) phenotypes among different bacteria $[13,14]$. The emergence of MDR bacteria are a serious threat to animal health, food safety, and human health [16]. Plasmids are often classified according to their incompatibility (Inc) groups, which is a phenomenon that inhibits coexistence of plasmids with the same replication and division mechanisms in the same cell [17]. Several MDR plasmids with different Inc types have been identified in Salmonella $[14,18]$. Among them, one of the key groups of antimicrobial resistance plasmids is the IncFIB plasmids that often carry multiple resistance determinants and virulence factors that may help bacterial pathogens improve survival capability in food animal environments and may cause infections in humans $[12,19]$.

Among the virulence factors present on many IncFIB plasmids, iron acquisition transport systems allow bacteria to survive in environments where iron is in limited supply [12]. Salmonella possess arrays of iron acquisition systems encoded on the chromosome and on plasmids $[8,12,20]$. These iron acquisition systems encoded on IncFIB plasmids are essential for the infection process of host cells $[8,12,21]$. A previous study showed that $15 \%$ of $S$. enterica isolates carried IncFIB plasmids that could increase Salmonella's ability to colonize the chicken cecum and cause gastrointestinal disease [22]. Moreover, IncFIB plasmids carry host addiction genes, such as $c c d A$, relB, and $v a g C$. These genes play a significant role in the stability of plasmids in the isolates $[23,24]$. However, much remains to be understood regarding genetic analysis of IncFIB plasmids associated with the impact on bacterial phenotype. With the advent and wide application of whole genome sequencing (WGS) over the last decade, there have been many advances in the understanding of microbial genetics. To better understand the natural history of IncFIB-positive $S$. Typhimurium isolates, this study included isolates from 1999 to 2003 and compared the findings to more recently sequenced strains. This study further characterized antimicrobial resistance and virulence in a set of IncFIB positive $S$. Typhimurium isolates, 
assessed the genomic and phenotypic characterization of IncFIB plasmids, and compared the relative virulence capacity of isolates and transconjugants.

\section{Materials and Methods}

\subsection{Bacterial Strains}

Seventy-one $S$. Typhimurium isolates were identified and phenotypically characterized by standard microbiological methods [13]. These isolates were retested by PCR to confirm the presence of the IncFIB replicon [25]. Isolates originated from chicken $(n=33,46 \%)$, turkey $(n=22,30 \%)$, cattle $(n=10,14 \%)$, swine $(n=4,5.4 \%)$, and poultry water $(n=2,3 \%)$ within the United States from 1999 to 2003. In addition, Escherichia coli J53 was used as a recipient strain for conjugation experiments [26]. Isolates were frozen at $-80{ }^{\circ} \mathrm{C}$ in brain heart Infusion broth (Remel, Lenexa, KS, USA) with $20 \%$ glycerol for long-term storage. To improve our understanding of the persistence and evolution of common antimicrobial resistance genotypes over the years, we obtained eight genome sequences of recently sequenced $S$. Typhimurium isolates from GenBank.

\subsection{Phenotypic Testing}

\subsubsection{Antimicrobial Drug Susceptibility Testing (AST)}

All isolates were examined for antimicrobial susceptibility testing (AST) using disc diffusion or broth microdilution following the standard Clinical and Laboratory Standards Institute (CLSI) guidelines [27-30]. Strains were tested for amoxicillin-clavulanic acid (AMC), amikacin (AMI), ampicillin (AMP), chloramphenicol (CHL), ciprofloxacin (CIP), gentamicin (GEN), kanamycin (KAN), streptomycin (STR), sulfisoxazole (SUL), trimethoprim-sulfamethoxazole (SXT), tetracycline (TET), and ceftiofur (TIO). E. coli ATCC 25922 was used as a quality control strain for the AST testing.

\subsubsection{Colicin Inhibition Assay}

The ability of Salmonella strains to produce colicin was evaluated by assessing the ability to potentially inhibit the growth of E. coli J53 strain [26]. The E. coli J53 test strain and each of the Salmonella test isolates were cross streaked on tryptic soy agar with 5\% sheep's blood (blood agar, Remel). Plates were incubated at $37^{\circ} \mathrm{C}$ for 16 to $18 \mathrm{~h}$, after which, plates were examined for growth inhibition of E. coli J53 at the intersection of Salmonella growth. If growth was inhibited, the strain was considered positive for colicin production.

\subsubsection{In Vitro Invasion and Persistence Assay}

Human intestinal epithelial cells (Caco-2) were grown in Dulbecco's Modified Eagle Medium (DMEM) containing $2.5 \mathrm{mM}$ L-glutamine supplemented with $5 \%$ fetal bovine serum (FBS) and penicillin-streptomycin-amphotericin (Gibco, Gaithersburg, MD, USA), in an atmosphere of 5\% $\mathrm{CO}_{2}$ at $37^{\circ} \mathrm{C}$. Cells were grown and maintained in the culture flask until reaching a complete monolayer. Upon confluence, cells were detached from the flask by incubating with $0.25 \%$ Trypsin-EDTA solution at $37^{\circ} \mathrm{C}$ for 2-3 min and washed with DMEM and re-suspended in complete DMEM media, without antibiotics. Epithelial cells were plated in 24-well culture plates at a concentration of $5 \times 10^{4}$ cells per well. Culture plates were incubated at $37{ }^{\circ} \mathrm{C}$ with $5 \% \mathrm{CO}_{2}$ and $95 \%$ humidity for $24 \mathrm{~h}$. Cells in one of the wells were counted using Cellometer Auto T4 (Nexcelom Bioscience, Lawrence, MA, USA). A subset of 37 Salmonella strains with varying PCR genotypes were selected for invasion and persistence assays.

Bacterial invasion assays were performed with a minor modification from a previously published protocol [14,31]. Caco-2 cells were infected with each of the strains at a multiplicity of infection (MOI) of 1:10. Each isolate was suspended in DMEM $\left(\sim 5 \times 10^{5}\right.$ cells/well $)$ and added to three wells containing Caco- 2 cells. Plates were centrifuged for $500 \mathrm{RPM}$ for $5 \mathrm{~min}$ and allowed to incubate for $1 \mathrm{~h}$ at $37^{\circ} \mathrm{C}$ in 
$5 \% \mathrm{CO}_{2}$. After a $1 \mathrm{~h}$ incubation, cells were washed with pre-warmed PBS (pH 7.4) three times to remove extracellular bacteria and incubated with $200 \mu \mathrm{g} / \mathrm{mL}$ of gentamicin (Life Technology, Grand Island, NY, USA) for $1 \mathrm{~h}$ at $37^{\circ} \mathrm{C}$ to kill the extracellular bacteria. After $1 \mathrm{~h}$ the cells were washed with PBS and incubated with chilled $1 \%$ Triton X-100 for $5 \mathrm{~min}$ at $37^{\circ} \mathrm{C}$ to lyse the Caco-2 cells. Aliquots were collected, serially diluted in PBS buffer, plated onto LB agar plates and incubated at $37^{\circ} \mathrm{C}$ for $18 \mathrm{~h}$. The colony forming units (CFUs) were determine by plate counting. These assays were performed in three independent replicates and repeated twice for a total of nine data points. Caco- 2 cells that were not infected with bacteria served as controls.

Persistence assay: For bacterial persistence determination, cells were infected with each of the Salmonella isolates as described for the invasion assay. After $1 \mathrm{~h}$ cells were washed with pre-warmed PBS and incubated with $100 \mu \mathrm{g} / \mathrm{mL}$ gentamicin for $48 \mathrm{~h}$ at $37^{\circ} \mathrm{C}$. After $48 \mathrm{~h}$ cells were washed with PBS and lysed with $1 \%$ Triton X-100. The numbers of surviving bacteria were determined by plating serial dilutions of cell lysates as described above.

\subsubsection{Conjugation Assay}

Salmonella isolates served as potential donor cells and E. coli J53 strain as the recipient cell for the conjugation experiments using methods previously described by Welch et al. (2007) with minor modifications [32]. Briefly, cultures of donor and recipient cells were sub-cultured on blood agar plates and incubated at $37^{\circ} \mathrm{C}$ for $24 \mathrm{~h}$. The following day, donor and recipient cells were mixed in $500 \mu \mathrm{L} \mathrm{LB}$ broth (1:1) and incubated at $37^{\circ} \mathrm{C}$ for $3 \mathrm{~h}$. Transconjugants were streaked on LB agar plates containing $16 \mu \mathrm{g} / \mathrm{mL}$ ampicillin, streptomycin, or tetracycline along with $300 \mu \mathrm{g} / \mathrm{mL}$ sodium azide and incubated for up to $48 \mathrm{~h}$. One colony from each plate was picked and plated on MacConkey agar (Remel) and incubated at $37^{\circ} \mathrm{C}$ for $24 \mathrm{~h}$. Transconjugants from MacConkey agar were sub-cultured on blood agar plates and incubated at $37^{\circ} \mathrm{C}$ for $24 \mathrm{~h}$. To identify which plasmids were transferred into the recipient cells, whole genome sequencing (WGS) was completed on transconjugant cells using the Illumina MiSeq as described below (Figure 1).

\subsection{Genotypic Testing}

\subsubsection{Whole Genome Sequencing (WGS)}

Genomic DNA of donor and transconjugant cells were extracted using a DNeasy Blood and Tissue kit (Qiagen, Valencia, CA, USA). DNA quality and quantity were measured using a Nanodrop (ThermoFisher Scientific, Grand Island, NY, USA) and Qubit BR assay (ThermoFisher Scientific). DNA libraries were constructed using 1 ng DNA from each sample using Nextera XT DNA library preparation kits (Illumina, San Diego, CA, USA). Samples were multiplexed using combinations of two indexes of Nextera XT Index Kit (Illumina). DNA samples were diluted, denatured, and loaded on an Illumina MiSeq instrument with a $2 \times 250$ pair-end format. Samples were sequenced in multiple batches.

\subsubsection{Single Nucleotide Polymorphism (SNP) Analysis}

Phylogenetic analysis of the sequenced Salmonella genomes $(n=71)$ was carried out to identify the core genome of isolates and build a phylogenetic tree using single nucleotide polymerase (SNP). A second tree was built incorporating sequence data from eight IncFIB-positive S. Typhimurium isolates collected from 2005-2018 to determine the relatedness of the more recently collected isolates to those collected earlier. These eight presumptive IncFIB-positive $S$. Typhimurium isolates were identified by BLAST searching with the IncFIB replicon sequence against $S$. Typhimurium genomes. Whole-genome sequence (WGS) data from isolates which originated from food animal sources within the United States after 2003, were downloaded from NCBI for subsequent SNP analyses. WGS-based single nucleotide polymorphism (SNP) analyses was performed using the FDA Center for Food Safety and Applied Nutrition (CFSAN) SNP pipeline as described by Davis et al. [33] installed on GalaxyTrakr 
(https://www.galaxytrakr.org) [34]. Briefly, a matrix of SNPs from WGS FastQ data were created using reference-based alignments by CFSAN SNP pipeline. Phylogenetic trees were constructed using the best scoring maximum likelihood (ML) SNP tree with randomized axelerated ML (RAxML) using a GTRGAMMA model with default parameter settings on GalaxyTrakr [35]. The SNP tree was generated by uploading FASTQ data of forward and reverse files of 71 isolates into GalaxyTrakr from a local computer (Figure 2). SNP trees were generated after downloading FASTQ data from 79 isolates from SRA submission using the SRA toolkit on GalaxyTrakr (Supplemental Figure S1). In both trees, SNPs matrix was built using Salmonella enterica serovar Typhimurium str. LT2 as reference genome (accession: NC_003197.2).

\subsubsection{Bioinformatic Analyses}

In this study we used a variety of sequence analysis applications to identify antimicrobial resistance and virulence genes encoded on plasmids. Genome sequences from $71 \mathrm{~S}$. Typhimurium isolates (donors) and 24 transconjugants were trimmed, and de novo assembly was completed using CLC Genomics Workbench (version. 9.0, Qiagen, Redwood City, CA, USA). FASTA files of sequence assemblies from each strain were analyzed using PlasmidFinder (version 2.1) and ResFinder (version 4.1) to identify predicted plasmids and antimicrobial resistance genes, respectively [36,37]. Pathosystems Resource Integration Center (PATRIC-database) [38] and an in-house Salmonella virulence factor database curated from PATRIC, Victor, VFDB, and the literature (NCTR Virulence Factor Database) were queried to identify putative virulence genes. Virulence genes were extracted from the in-house database (NCTR-database), transformed to binary data and imported into BioNumerics for phylogenetic analysis using Dice Coefficients and UPGMA (Applied Maths, Austin, TX, USA). The Basic Local Alignment Search Tools (BLAST) were used to identify plasmid transfer-associated genes and colicin genes.

\subsubsection{Bioinformatic Analyses}

In this study we used a variety of sequence analysis applications to identify antimicrobial resistance and virulence genes encoded on plasmids. Genome sequences from $71 \mathrm{~S}$. Typhimurium isolates (donors) and 24 transconjugants were trimmed, and de novo assembly was completed using CLC Genomics Workbench (version. 9.0, Qiagen, Redwood City, CA, USA). FASTA files of sequence assemblies from each strain were analyzed using PlasmidFinder (version 2.1) and ResFinder (version 4.1) to identify predicted plasmids and antimicrobial resistance genes, respectively [36,37]. Pathosystems Resource Integration Center (PATRIC-database) [38] and an in-house Salmonella virulence factor database curated from PATRIC, Victor, VFDB, and the literature (NCTR Virulence Factor Database) were queried to identify putative virulence genes. Virulence genes were extracted from the in-house database (NCTR-database), transformed to binary data and imported into BioNumerics for phylogenetic analysis using Dice Coefficients and UPGMA (Applied Maths, Austin, TX). The Basic Local Alignment Search Tools (BLAST) were used to identify plasmid transfer-associated genes and colicin genes.

\subsection{Statistical Analysis}

Data were imported into Excel (Microsoft, Redmond, WA, USA) and two-tailed T-tests were used to determine statistical differences between cell survival of invasion and persistence ratio, with a $p$-value $\leq 0.05$ considered as a significant difference between two groups. 

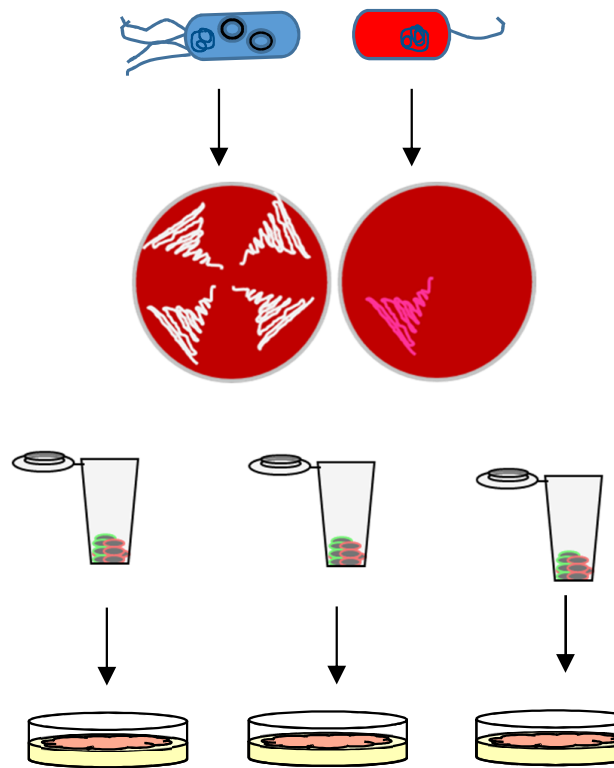

Picked and mixed donor and recipient isolates in $500 \mu \mathrm{LB}$ broth (1:1) and incubated at $35^{\circ} \mathrm{C}$ for $3 \mathrm{~h}$.

Streaked on LB agar has $16 \mu \mathrm{g} / \mathrm{mL}$ ampicillin, streptomycin, or tetracycline along with $300 \mu \mathrm{g} / \mathrm{mL}$ sodium azide and Incubated at $35^{\circ} \mathrm{C}$ for $24-48 \mathrm{~h}$.
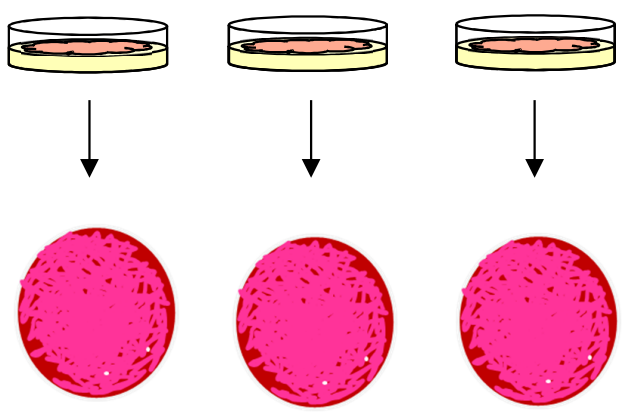

$\downarrow$
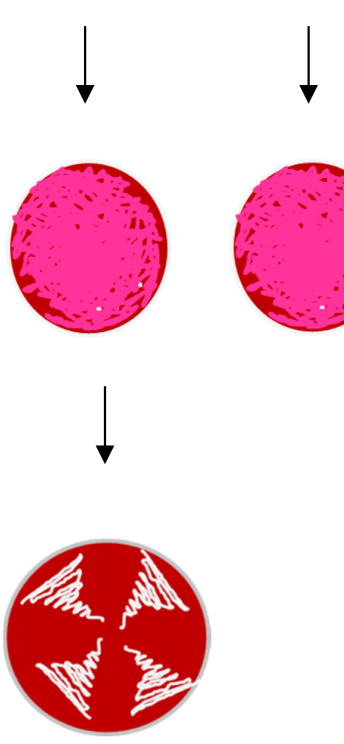

one colony from LB agar and streaked on MacConkey agar. Then incubated at $35^{\circ} \mathrm{C}$ for $24 \mathrm{~h}$.

Recipient cells were sub-cultured on blood agar plates and incubated at $35^{\circ} \mathrm{C}$ for $24 \mathrm{~h}$.

Prepared DNA libraries using Nextera XT Kits and sequenced using an Illumina (MiSeq).

Figure 1. Schematic of conjugation process of Donor S. Typhimurium and E. coli J53. 


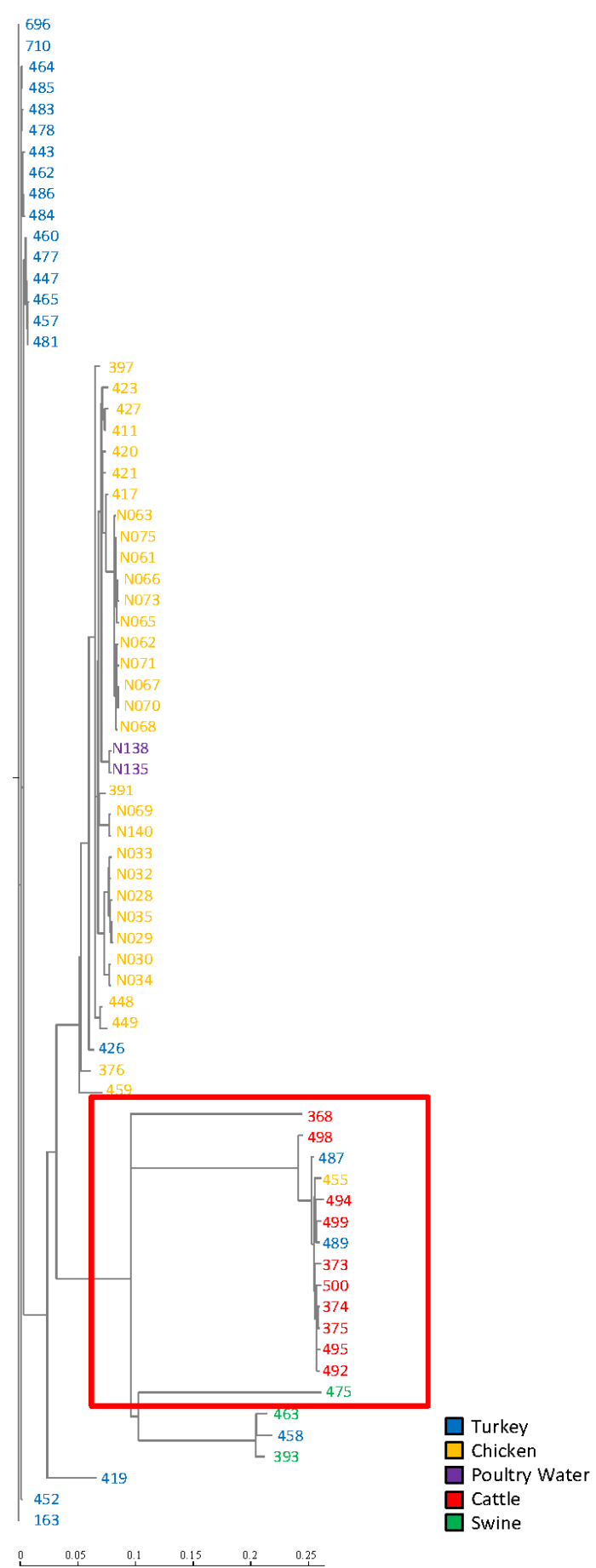

Figure 2. Phylogenetic analysis for $71 \mathrm{~S}$. Typhimurium. SNP analysis indicates most of the isolates clustered together based on the host origin and some iosolates grouped together based on geographic region. The red box indicates spv genes were found in these isolates. The numbers on the scale present the percentage of genetic variation.

\section{Results}

The study used multiple experiments to analyze genotypic and phenotypic characteristics associated with IncFIB plasmid-positive Salmonella enterica serovar Typhimurium isolates originating from different food animal sources. Sequencing assemblies of all isolates were submitted to NCBI under the accession numbers listed in Table 1. Using SNP-based phylogenetic analyses, the genetic structure of most $S$. Typhimurium isolates clustered together based on host origin. Isolates that originated from 
chickens typically clustered to those isolates collected from turkey sources. These poultry-associated isolates were in distinctly different phylogenetic clades from those isolates collected from swine and cattle. Many of these isolates originating from chickens and poultry water were collected from West Virginia and clustered together, which likly indicated that same or similar strains circulating in the close geographic region. Likewise, isolates 373, 374, and 375 originating from cattle in Michigan grouped together; however, these also clustered with other strains from cattle and poultry indicating that this genotype may have been more widely distributed (Figure 2). Furthermore, the SNP based evolutionary tree showed $S$. Typhimurium isolates of the current study were phylogenetic clades from eight genome sequences of the more recently sequenced $S$. Typhimurium isolates (Figure S1). These isolates shared a high degree of genetic relatedness and carried similar virulence and antimicrobial resistance genes, including $a p h(3 ")-I b$, aph (6)-Id, bla $a_{T E M-1 B}, b l a_{C M Y-2}, \operatorname{sul2}$, tet $(A)$, tet $(B)$, tet $(G)$, sul1, and sul2 (Figure 3; Tables S1 and S2).

Table 1. Isolate information for 71 Salmonella enterica serovar Typhimurium.

\begin{tabular}{|c|c|c|c|c|}
\hline Isolate & Source & Isolation Location & Year & GenBank Accession \\
\hline 163 & Turkey & $\mathrm{OH}$ & 1999 & LSZD00000000 \\
\hline 368 & Cattle & GA & 1999 & PDNO00000000 \\
\hline 373 & Cattle & MI & 1999 & PDNN00000000 \\
\hline 374 & Cattle & MI & 1999 & VTSM00000000 \\
\hline 375 & Cattle & MI & 1999 & VTSL00000000 \\
\hline 376 & Chicken & GA & 1999 & PDNM00000000 \\
\hline 391 & Chicken & USA & 1999 & VTSK00000000 \\
\hline 393 & Swine & USA & 1999 & VSXW00000000 \\
\hline 397 & Chicken & USA & 1999 & LYRR00000000 \\
\hline 411 & Chicken & USA & 1999 & VSXV00000000 \\
\hline 417 & Chicken & USA & 1999 & VSXU00000000 \\
\hline 419 & Swine & USA & 1999 & VSXT00000000 \\
\hline 420 & Chicken & USA & 1999 & VSXS00000000 \\
\hline 421 & Chicken & USA & 1999 & VSXI00000000 \\
\hline 423 & Chicken & USA & 1999 & VSXR00000000 \\
\hline 426 & Turkey & USA & 1999 & PDNK00000000 \\
\hline 427 & Chicken & USA & 1999 & VSXQ00000000 \\
\hline 443 & Turkey & USA & 1999 & VSXP00000000 \\
\hline 447 & Turkey & USA & 1999 & VSXO00000000 \\
\hline 448 & Chicken & USA & 1999 & VSXN00000000 \\
\hline 449 & Chicken & USA & 1999 & VSXM00000000 \\
\hline 452 & Turkey & USA & 1999 & LYRS00000000 \\
\hline 455 & Chicken & USA & 1999 & VSXL00000000 \\
\hline
\end{tabular}


Table 1. Cont.

\begin{tabular}{|c|c|c|c|c|}
\hline Isolate & Source & Isolation Location & Year & GenBank Accession \\
\hline 457 & Turkey & USA & 1999 & VSXH00000000 \\
\hline 458 & Turkey & USA & 1999 & VSXK00000000 \\
\hline 459 & Chicken & USA & 1999 & VTSH00000000 \\
\hline 460 & Turkey & USA & 1999 & VTSI00000000 \\
\hline 462 & Turkey & USA & 1999 & VTSU00000000 \\
\hline 463 & Swine & USA & 1999 & PHGW00000000 \\
\hline 464 & Turkey & USA & 1999 & VSXG00000000 \\
\hline 465 & Turkey & USA & 1999 & VTSG00000000 \\
\hline 475 & Swine & USA & 1999 & VSXJ00000000 \\
\hline 477 & Turkey & USA & 1999 & VTSF00000000 \\
\hline 478 & Turkey & USA & 1999 & LYRT00000000 \\
\hline 481 & Turkey & USA & 1999 & VSXF00000000 \\
\hline 483 & Turkey & USA & 1999 & VTSD00000000 \\
\hline 484 & Turkey & USA & 1999 & PDOI00000000 \\
\hline 485 & Turkey & USA & 1999 & VSXE00000000 \\
\hline 486 & Turkey & USA & 1999 & VTSC00000000 \\
\hline 487 & Turkey & USA & 1999 & VSXD00000000 \\
\hline 489 & Turkey & USA & 1999 & VTSB00000000 \\
\hline 492 & Cattle & USA & 1999 & PDOJ00000000 \\
\hline 494 & Cattle & USA & 1999 & PDOK00000000 \\
\hline 495 & Cattle & USA & 1999 & VTSA00000000 \\
\hline 498 & Cattle & USA & 1999 & VSXC00000000 \\
\hline 499 & Cattle & WV & 1999 & VTRZ00000000 \\
\hline 500 & Cattle & USA & 1999 & VSXB00000000 \\
\hline 696 & Turkey & USA & 1999 & LXHA00000000 \\
\hline 710 & Turkey & ND & 1999 & LXGZ00000000 \\
\hline N028 & Chicken & WV & 2003 & VSWY00000000 \\
\hline N029 & Chicken & WV & 2003 & VSXA00000000 \\
\hline N030 & Chicken & WV & 2003 & VSWX00000000 \\
\hline N032 & Chicken & WV & 2003 & VSWZ00000000 \\
\hline N033 & Chicken & WV & 2003 & VTRY00000000 \\
\hline N034 & Chicken & WV & 2003 & VSWW00000000 \\
\hline N035 & Chicken & WV & 2003 & VSWV00000000 \\
\hline N061 & Chicken & WV & 2003 & VSWU00000000 \\
\hline N062 & Chicken & WV & 2003 & VTRX00000000 \\
\hline N063 & Chicken & WV & 2003 & VSWT00000000 \\
\hline N065 & Chicken & WV & 2003 & VSWS00000000 \\
\hline
\end{tabular}


Table 1. Cont.

\begin{tabular}{ccccc}
\hline Isolate & Source & Isolation Location & Year & GenBank Accession \\
\hline N066 & Chicken & WV & 2003 & VSWR00000000 \\
\hline N067 & Chicken & WV & 2003 & VSWQ00000000 \\
\hline N068 & Chicken & WV & 2003 & VSWP00000000 \\
\hline N069 & Chicken & WV & 2003 & VSWO00000000 \\
\hline N070 & Chicken & WV & 2003 & VSWN00000000 \\
\hline N071 & Chicken & WV & 2003 & VSWM00000000 \\
\hline N073 & Chicken & WV & 2003 & VTRW00000000 \\
\hline N075 & Chicken & WV & 2003 & VSWL00000000 \\
\hline N135 & $\begin{array}{c}\text { Poultry } \\
\text { Water }\end{array}$ & WV & 2003 & VSWK00000000 \\
\hline N138 & $\begin{array}{c}\text { Poultry } \\
\text { Water }\end{array}$ & WV & 2003 & VSWJ00000000 \\
\hline N140 & Chicken & WV & 2003 & VSWI00000000 \\
\hline
\end{tabular}

USA: State-level information not available; OH: Ohio; GA: Georgia; MI: Michigan; ND: North Dakota; WV: West Virginia.

All 71 strains were used as donors for conjugation and 24 strains (34\%) were able to generate transconjugants. Each isolate and transconjugant underwent WGS analyses to identify antimicrobial resistance genes, putative virulence factors, bacteriocin genes and transfer-associated genes. Results of phylogenetic analyses with BioNumerics based on the presence of the virulence factors for $71 \mathrm{~S}$. Typhimurium are displayed in Figure 3 and Table S3. The NCTR virulence factor database identified putative virulence factors and the heatmap indicated the presence or absence of specific virulence genes for 71 isolates. Most of the isolates had very similar virulence factor profiles, with the noted exception of isolate 475 , which was most distant from the other isolates. Of note 475 carried operons for multiple fimbriae (pef and sef) and sugar efflux transport (set) that were not present in any of the other isolates and carried the spv-containing virulence plasmid that was present in $14(20 \%)$ of the isolates (Table S3). The invasion and persistence results for 37 isolates that can invade Caco-2 cells are presented in Figure 4. Nine of $37(24 \%)$ isolates displayed significantly higher cell numbers at $48 \mathrm{~h}$ of persistence, compared to the $1 \mathrm{~h}$ invasion period. Likewise, seven isolates (19\%) displayed increased bacterial cell numbers after $48 \mathrm{~h}$ of infection which did not reach significant differences between two groups. Conversely, three of $37(8 \%)$ isolates demonstrated significantly higher bacterial cell counts after $1 \mathrm{~h}$, compared to a $48 \mathrm{~h}$ incubation period, while 18 out of $37(49 \%)$ isolates exhibited higher numbers of bacterial cells after $1 \mathrm{hr}$ of invasion which did not reach statistical significance. When looking at the invasion and persistence results compared to either the virulence factor profiles and SNP analyses, there is not a clear trend that explains the variability in the persistence findings. All of the isolates contained the genes encoding Salmonella pathogenicity island-1 (SP-1) encoded type III secretion system (T3SS), which facilitated their ability to invade the host cells and Salmonella pathogenicity island-2 (SP-2) associated with the persistence of the Salmonella in host cells (Tables S1 and S3). Further efforts to understand the variability in persistence are needed, for example is there a role of the co-localization with other plasmids in persistence. Interestingly of the 13 strains tested that carried both IncFIB and Inc $A / C$ plasmids, six had significantly greater persistence and four displayed increased bacterial cell numbers after $48 \mathrm{hr}$ of infection which did not reach significance. These numbers are $67 \%(6 / 9)$ and $57 \%$ (4/7) of the strains that fell into these persistence categories, respectively. Two of the remaining three IncA/C positive strains had fairly large standard error bars with the persistence range larger than that of the invasion. Whether there is a link between the plasmids and persistence merits further evaluation. 


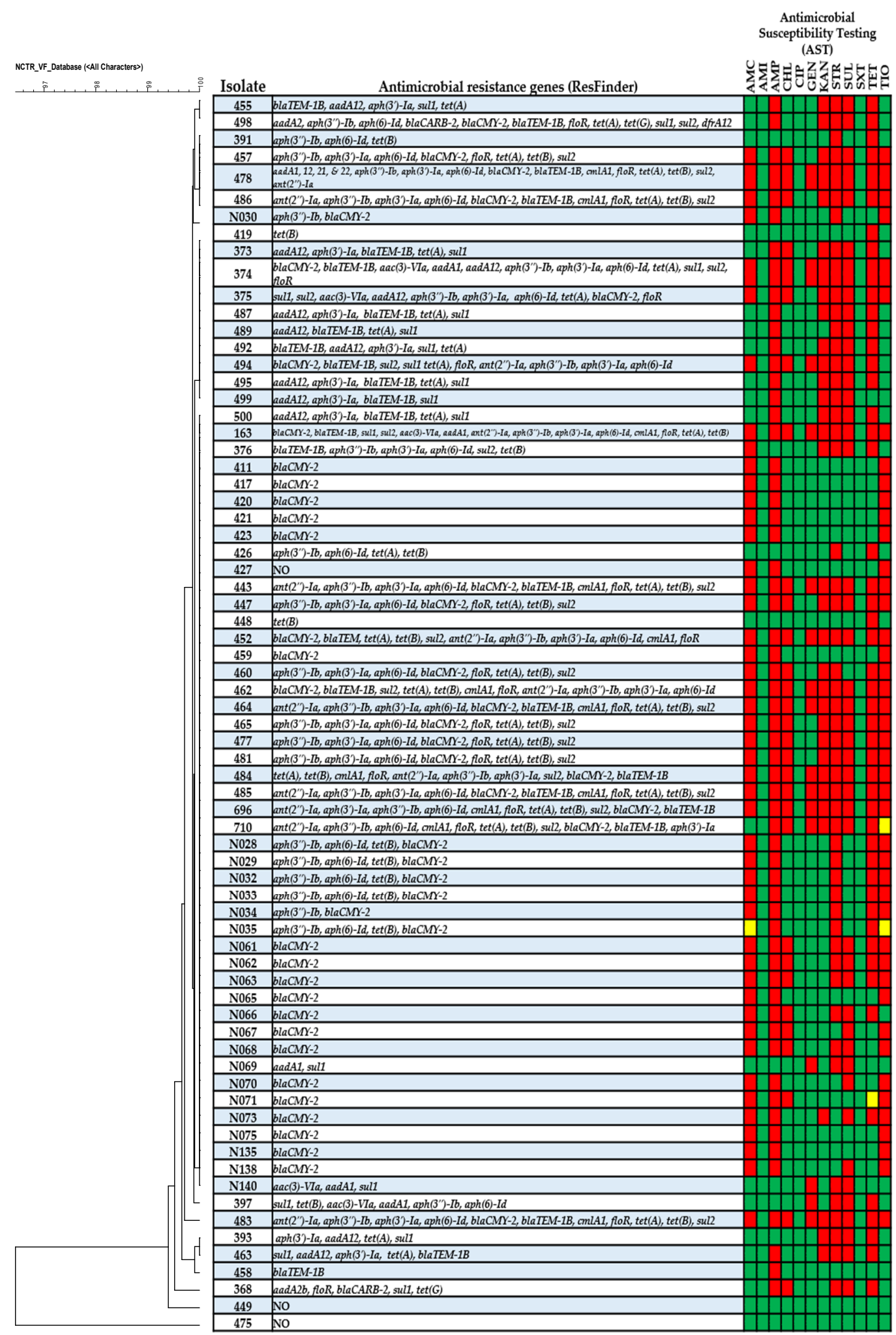

Figure 3. Virulence gene profile comparison and antimicrobial resistance characterization of the 71 Salmonella isolates. The dendrogram on the left is based on the phylogenetic comparison of 491 virulence or putative virulence genes described in Table S3. The columns to the right display the resistance genes identified and antimicrobial susceptibility testing results, where a red box indicates resistance, a green box susceptible and a yellow box indicates intermediate susceptible. 
The results of colicin inhibition and detection of the colicin-associated genes for all isolates are shown in Table 2. Twenty-one isolates ( $29 \%$ ) were able to inhibit the growth of E. coli J53. All isolates that inhibited E. coli J53 growth carried the channel-forming colicin genes cia and cib and the colicin b immunity ( $\mathrm{imm}$ ) genes, while $17(23 \%)$ were positive for the $c v a$ colicin production gene, with isolates N065, N068, N071, and N073 lacking cva. Among the conjugation-related genes, the WGS data using PATRIC and BLAST identified pil and tra genes, which are the most representative genes in the isolates. Most of the isolates contained traT $(n=68,95 \%)$, traJ $(n=38,53 \%)$, and $(n=32,45 \%)$ carried pilPM, followed by pilJ $(n=31,44 \%)$, and pill $(n=5,7 \%)$. Only $24(34 \%)$ strains were able to generate transconjugants using the methods employed in this project (Table 2).

WGS analyses using PlasmidFinder software confirmed that all isolates contained IncFIB plasmids along with multiple other plasmid replicon types, including IncFIC(FII) $(n=34,48 \%)$, IncFIA $(n=23$, $23 \%)$, IncFII(pCoo) $(n=19,27 \%), \operatorname{IncFII}(\mathrm{S})(n=14,20 \%)$, ColpVC $(n=44,62 \%)$, IncI1 $(n=32,45 \%)$, IncA/C2 $(n=20,28 \%), \operatorname{IncX} 1(n=11,15 \%), \operatorname{IncHI} 2(n=8,11 \%), \operatorname{IncHI} 2 \mathrm{~A}(n=8,11 \%)$, and IncX4 $(n=3$, $4.2 \%)$. PlasmidFinder analyses confirmed that seventeen transconjugants contained IncFIB plasmids $(n=17,71 \%)$ along with other plasmid replicon types, including IncFIA $(n=16,67 \%)$, IncFII(pCoo) $(n=16,67 \%)$, IncI1 $(n=5,21 \%), \operatorname{IncA} / C 2(n=3,12.5 \%)$, IncColpVC $(n=2,8.3 \%)$, and IncX4 $(n=1,4 \%)$. These results demonstrate that the distribution of plasmids to the recipient $E$. coli J53 can be variable. In some cases the plasmids, like the IncFIB plasmids, are not being transferred conjugally even though the donor carried the plasmid type (Table 3).

PATRIC and BLAST software identified putative virulence factors, including iron acquisition genes. All the Salmonella strains were positive for Salmochelin siderophore system genes (iro), but none of the transconjugants carried them. Salmonella isolates carried the aerobactin iron acquisition system iucABCD $(n=5375 \%)$ and iutA $(n=67,94 \%)$ genes, while some transconjugants also contained iuc $A B C D(n=13,54 \%)$ and iut $A(n=16,66 \%)$. The regulated iron transporter system $(\operatorname{sit} A B C D)$ was found in 54 isolates $(76 \%)$, followed by sit $A B(n=17,24 \%)$, and 13 transconjugants carried sit $A B C D$ (54\%). Remarkably, seven of transconjugants lacked the iron acquisition genes because the IncFIB plasmids associated with iron acquisition genes were not transferred to the transconjugants generated (Table 3). In addition, virulence factor analyses identified the Salmonella plasmid virulence gene (spv) in some isolates $(n=14,20 \%)$, but none of transconjugants (Table 4 andTable S3). Most spv was found in cattle $(n=10)$, and other sources, including turkey $(n=2)$, swine $(n=1)$, and chicken $(n=1)$; each of these isolates, with the exception of 475 , clustered together and shared a common ancestor (LCA), as shown in the red box Figure 2.

In addition, WGS data was analyzed using ResFinder software to identify antimicrobial resistance genes commonly associated with IncFIB plasmid positive $S$. Typhimurium isolates. ResFinder software revealed that 24 of the transconjugants carried multiple antimicrobial resistance genes that were obtained from the donor cells via conjugation, listed in Table 4. AST identified Salmonella isolates that were resistant to AMP $(n=59,83 \%)$, AMC $(n=46,65 \%)$, TIO $(n=43,61 \%)$, CHL $(n=22,31 \%)$, GEN $(n=15,21 \%)$, KAN $(n=31,44 \%)$, STR $(n=46,65 \%)$, SUL $(n=36,51 \%)$, and TET $(n=43,61 \%)$. Only two strains showed intermediate susceptibility to TIO $(n=2,4 \%)$ followed by TET $(n=1,2 \%)$, and $\operatorname{AMC}(n=1,2 \%)$. For the corresponding resistance genotypes $(n=48,68 \%)$ strains carried bla $_{C M Y-2}$, followed by bla $a_{T E M-1 B}(n=22,31 \%)$, bla $\operatorname{laARB-2}_{2}(n=2,3 \%), \operatorname{bla}_{T E M}(n=1,2 \%)$, floR $(n=23$, $32 \%)$, cmlA1 $(n=12,17 \%)$, ant (2")-Ia $(n=12,17 \%)$, aac (3)-Via $(n=5,7 \%)$, aph(3")-Ia $(n=31,44 \%)$, $\operatorname{aph}\left(3^{\prime \prime}\right)-I b(n=32,45 \%)$, aph(6)-Id $(n=30,42 \%)$, aadA12 $(n=9,16 \%)$, aadA1 $(n=4,7.3 \%)$, aadA2b $(n=1$, $2 \%)$, aadA21 $(n=1,2 \%)$, aadA22 $(n=1,2 \%)$, sul1 $(n=18,25 \%)$, sul2 $(n=21,30 \%)$, tet $(A)(n=32,45 \%)$, $\operatorname{tet}(B)(n=28,39 \%)$, and $\operatorname{tet}(G)(n=2,3 \%)$, presented in Figure 3 . 


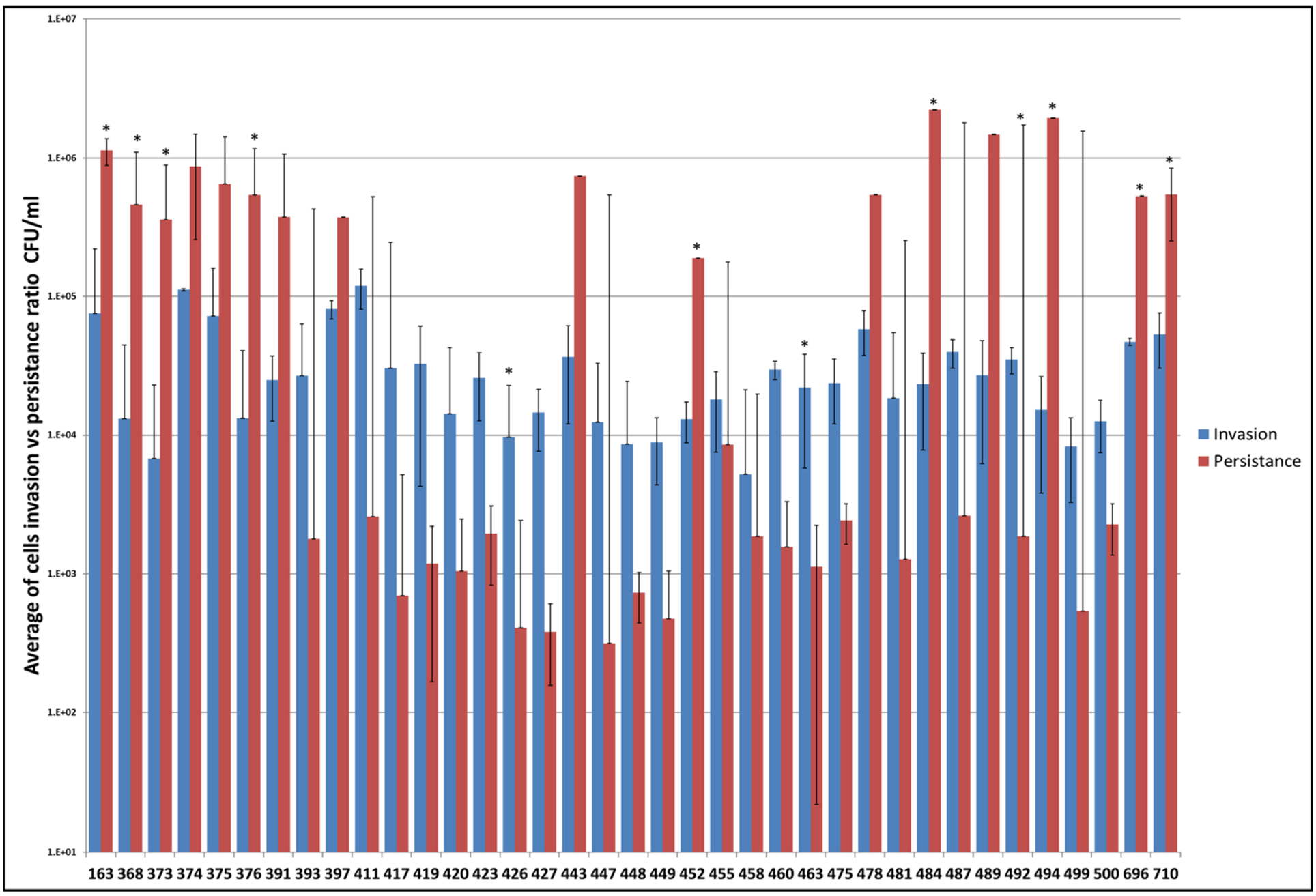

Figure 4. Results of the invasion and persistence studies of $37 \mathrm{~S}$. Typhimurium. The bacterial invasion (blue bars) indicated the means of ratio cells detected after a $1 \mathrm{~h}$ invasion and the bacterial persistence (red bars) indicted the means of the ratio cells detected after a $48 \mathrm{~h}$ persistence. The error bars show the standard error of means. $\left.{ }^{*}\right)$ determined the significant differences between two groups. 
Table 2. Phenotypic and genomic results of colicin and conjugation assays for 71 isolates.

\begin{tabular}{|c|c|c|c|c|c|c|c|c|}
\hline \multirow[b]{2}{*}{ Isolate } & \multicolumn{2}{|c|}{ Plasmid Transfer-Associated Genes } & \multirow{2}{*}{ Conjugation } & \multicolumn{4}{|c|}{ Colicin Genes } & \multirow[b]{2}{*}{ Colicin Inhibition } \\
\hline & $\begin{array}{c}\text { Type IV Pilus } \\
\text { Biogenesis Protein }\end{array}$ & Tra Genes & & $\begin{array}{c}\text { Colicin Ia } \\
\text { Synthesis Protein }\end{array}$ & Colicin Ib Protein & $\begin{array}{c}\text { Colicin V } \\
\text { Synthesis Protein }\end{array}$ & $\begin{array}{c}\text { Colicin Ib } \\
\text { Immunity Protein }\end{array}$ & \\
\hline 163 & pilJPM & traTJ & YES & cia & $c i b$ & $\mathrm{~N}$ & $i m m$ & NO \\
\hline 368 & $\mathrm{~N}$ & $\operatorname{traT}$ & $\mathrm{NO}$ & $\mathrm{N}$ & $\mathrm{N}$ & $\mathrm{N}$ & $\mathrm{N}$ & NO \\
\hline 373 & $\mathrm{~N}$ & $\operatorname{traT}$ & NO & $\mathrm{N}$ & $\mathrm{N}$ & $\mathrm{N}$ & $\mathrm{N}$ & NO \\
\hline 374 & pillJPM & traTJ & $\mathrm{NO}$ & $\mathrm{N}$ & $\mathrm{N}$ & $\mathrm{N}$ & $\mathrm{N}$ & NO \\
\hline 375 & pillJPM & traTJ & YES & $\mathrm{N}$ & $\mathrm{N}$ & $\mathrm{N}$ & $\mathrm{N}$ & NO \\
\hline 376 & $\mathrm{~N}$ & $\operatorname{traT}$ & NO & $\mathrm{N}$ & $\mathrm{N}$ & $\mathrm{N}$ & $\mathrm{N}$ & NO \\
\hline 391 & $\mathrm{~N}$ & traT & NO & $\mathrm{N}$ & $\mathrm{N}$ & $c v a A B C$ & $\mathrm{~N}$ & NO \\
\hline 393 & pillJPM & traTJ & YES & $\mathrm{N}$ & $\mathrm{N}$ & $\mathrm{N}$ & $\mathrm{N}$ & $\mathrm{NO}$ \\
\hline 397 & pilJPM & traJ & $\mathrm{NO}$ & $c i a$ & $c i b$ & $\mathrm{~N}$ & $\mathrm{~N}$ & $\mathrm{NO}$ \\
\hline 411 & pilJPM & traTJ & $\mathrm{NO}$ & cia & $c i b$ & $c v a B C$ & imm & YES \\
\hline 417 & pilJPM & traTJ & NO & cia & $c i b$ & $\mathrm{~N}$ & imm & $\mathrm{NO}$ \\
\hline 419 & $N$ & $\mathrm{~N}$ & $\mathrm{NO}$ & $\mathrm{N}$ & $\mathrm{N}$ & $\mathrm{N}$ & $\mathrm{N}$ & $\mathrm{NO}$ \\
\hline 420 & pilJPM & traTJ & $\mathrm{NO}$ & cia & $c i b$ & $c v a B C$ & $i m m$ & YES \\
\hline 421 & pilJPM & traTJ & $\mathrm{NO}$ & cia & $c i b$ & $c v a A B C$ & imm & YES \\
\hline 423 & pilJPM & traTJ & $\mathrm{NO}$ & cia & $c i b$ & $c v a A B C$ & $i m m$ & YES \\
\hline 426 & pilPM & traTJ & $\mathrm{NO}$ & $\mathrm{N}$ & $\mathrm{N}$ & $c v a A B C$ & $\mathrm{~N}$ & YES \\
\hline 427 & $\mathrm{~N}$ & traT & NO & $\mathrm{N}$ & $\mathrm{N}$ & $c v a A B C$ & $\mathrm{~N}$ & NO \\
\hline 443 & $\mathrm{~N}$ & traT & YES & $\mathrm{N}$ & $\mathrm{N}$ & $\mathrm{N}$ & $\mathrm{N}$ & NO \\
\hline 447 & $\mathrm{~N}$ & $\operatorname{traT}$ & YES & $\mathrm{N}$ & $\mathrm{N}$ & $\mathrm{N}$ & $\mathrm{N}$ & NO \\
\hline 448 & $\mathrm{~N}$ & traT & $\mathrm{NO}$ & $\mathrm{N}$ & $\mathrm{N}$ & $\mathrm{N}$ & $\mathrm{N}$ & $\mathrm{NO}$ \\
\hline 449 & $\mathrm{~N}$ & traT & $\mathrm{NO}$ & $\mathrm{N}$ & $\mathrm{N}$ & $\mathrm{N}$ & $\mathrm{N}$ & NO \\
\hline 452 & $\mathrm{~N}$ & traT & YES & $\mathrm{N}$ & $\mathrm{N}$ & $\mathrm{N}$ & $\mathrm{N}$ & $\mathrm{NO}$ \\
\hline 455 & $\mathrm{~N}$ & traT & $\mathrm{NO}$ & $\mathrm{N}$ & $\mathrm{N}$ & $\mathrm{N}$ & $\mathrm{N}$ & $\mathrm{NO}$ \\
\hline 457 & $\mathrm{~N}$ & traTJ & YES & $\mathrm{N}$ & $\mathrm{N}$ & $\mathrm{N}$ & $\mathrm{N}$ & $\mathrm{NO}$ \\
\hline 458 & pillJPM & traTJ & YES & $\mathrm{N}$ & $\mathrm{N}$ & $\mathrm{N}$ & $\mathrm{N}$ & $\mathrm{NO}$ \\
\hline 459 & pilJPM & traTJ & YES & cia & $c i b$ & $c v a A B C$ & $i m m$ & YES \\
\hline
\end{tabular}


Table 2. Cont

\begin{tabular}{|c|c|c|c|c|c|c|c|c|}
\hline \multirow[b]{2}{*}{ Isolate } & \multicolumn{2}{|c|}{ Plasmid Transfer-Associated Genes } & \multirow{2}{*}{ Conjugation } & \multicolumn{4}{|c|}{ Colicin Genes } & \multirow[b]{2}{*}{ Colicin Inhibition } \\
\hline & $\begin{array}{c}\text { Type IV Pilus } \\
\text { Biogenesis Protein }\end{array}$ & Tra Genes & & $\begin{array}{c}\text { Colicin Ia } \\
\text { Synthesis Protein }\end{array}$ & Colicin Ib Protein & $\begin{array}{c}\text { Colicin V } \\
\text { Synthesis Protein }\end{array}$ & $\begin{array}{c}\text { Colicin Ib } \\
\text { Immunity Protein }\end{array}$ & \\
\hline 460 & $\mathrm{~N}$ & traT & YES & $\mathrm{N}$ & $\mathrm{N}$ & $\mathrm{N}$ & $\mathrm{N}$ & NO \\
\hline 462 & $\mathrm{~N}$ & $\operatorname{traT}$ & YES & $\mathrm{N}$ & $\mathrm{N}$ & $\mathrm{N}$ & $\mathrm{N}$ & NO \\
\hline 463 & pillJPM & traTJ & YES & $\mathrm{N}$ & $\mathrm{N}$ & $\mathrm{N}$ & $\mathrm{N}$ & NO \\
\hline 464 & $\mathrm{~N}$ & traT & YES & $\mathrm{N}$ & $\mathrm{N}$ & $\mathrm{N}$ & $\mathrm{N}$ & NO \\
\hline 465 & $\mathrm{~N}$ & $\operatorname{traT}$ & YES & $\mathrm{N}$ & $\mathrm{N}$ & $\mathrm{N}$ & $\mathrm{N}$ & NO \\
\hline 475 & $\mathrm{~N}$ & $\mathrm{~N}$ & $\mathrm{NO}$ & $\mathrm{N}$ & $\mathrm{N}$ & $\mathrm{N}$ & $\mathrm{N}$ & NO \\
\hline 477 & $\mathrm{~N}$ & traT & YES & $\mathrm{N}$ & $\mathrm{N}$ & $\mathrm{N}$ & $\mathrm{N}$ & NO \\
\hline 478 & $\mathrm{~N}$ & traT & YES & $\mathrm{N}$ & $\mathrm{N}$ & $\mathrm{N}$ & $\mathrm{N}$ & $\mathrm{NO}$ \\
\hline 481 & $\mathrm{~N}$ & traT & $\mathrm{NO}$ & $\mathrm{N}$ & $\mathrm{N}$ & $\mathrm{N}$ & $\mathrm{N}$ & $\mathrm{NO}$ \\
\hline 483 & $\mathrm{~N}$ & $\operatorname{traT}$ & $\mathrm{NO}$ & $\mathrm{N}$ & $\mathrm{N}$ & $\mathrm{N}$ & $\mathrm{N}$ & NO \\
\hline 484 & $\mathrm{~N}$ & traT & NO & $\mathrm{N}$ & $\mathrm{N}$ & $\mathrm{N}$ & $\mathrm{N}$ & $\mathrm{NO}$ \\
\hline 485 & $\mathrm{~N}$ & traT & YES & $\mathrm{N}$ & $\mathrm{N}$ & $\mathrm{N}$ & $\mathrm{N}$ & NO \\
\hline 486 & $\mathrm{~N}$ & traT & YES & $\mathrm{N}$ & $\mathrm{N}$ & $\mathrm{N}$ & $\mathrm{N}$ & NO \\
\hline 487 & $\mathrm{~N}$ & traT & $\mathrm{NO}$ & $\mathrm{N}$ & $\mathrm{N}$ & $\mathrm{N}$ & $\mathrm{N}$ & NO \\
\hline 489 & $\mathrm{~N}$ & traT & $\mathrm{NO}$ & $\mathrm{N}$ & $\mathrm{N}$ & $\mathrm{N}$ & $\mathrm{N}$ & $\mathrm{NO}$ \\
\hline 492 & $\mathrm{~N}$ & traT & $\mathrm{NO}$ & $\mathrm{N}$ & $\mathrm{N}$ & $\mathrm{N}$ & $\mathrm{N}$ & $\mathrm{NO}$ \\
\hline 494 & $\mathrm{~N}$ & traT & YES & $\mathrm{N}$ & $\mathrm{N}$ & $\mathrm{N}$ & $\mathrm{N}$ & NO \\
\hline 495 & $\mathrm{~N}$ & $\operatorname{traT}$ & NO & $\mathrm{N}$ & $\mathrm{N}$ & $\mathrm{N}$ & $\mathrm{N}$ & NO \\
\hline 498 & pilJPM & traTJ & NO & cia & $c i b$ & $\mathrm{~N}$ & $\mathrm{~N}$ & NO \\
\hline 499 & $\mathrm{~N}$ & traT & $\mathrm{NO}$ & $\mathrm{N}$ & $\mathrm{N}$ & $\mathrm{N}$ & $\mathrm{N}$ & $\mathrm{NO}$ \\
\hline 500 & $\mathrm{~N}$ & traT & $\mathrm{NO}$ & $\mathrm{N}$ & $\mathrm{N}$ & $\mathrm{N}$ & $\mathrm{N}$ & $\mathrm{NO}$ \\
\hline 696 & $\mathrm{~N}$ & traT & $\mathrm{NO}$ & $\mathrm{N}$ & $\mathrm{N}$ & $\mathrm{N}$ & $\mathrm{N}$ & $\mathrm{NO}$ \\
\hline 710 & $\mathrm{~N}$ & traT & YES & $\mathrm{N}$ & $\mathrm{N}$ & $\mathrm{N}$ & $\mathrm{N}$ & NO \\
\hline N028 & $\mathrm{N}$ & traTJ & NO & cia & $c i b$ & $c v a A B$ & imm & YES \\
\hline N029 & $\mathrm{N}$ & traTJ & YES & cia & $c i b$ & $c v a A B$ & $i m m$ & YES \\
\hline N030 & pilJPM & traTJ & YES & cia & $c i b$ & $c v a A B$ & $\mathrm{imm}$ & YES \\
\hline
\end{tabular}


Table 2. Cont

\begin{tabular}{|c|c|c|c|c|c|c|c|c|}
\hline \multirow[b]{2}{*}{ Isolate } & \multicolumn{2}{|c|}{ Plasmid Transfer-Associated Genes } & \multirow[b]{2}{*}{ Conjugation } & \multicolumn{4}{|c|}{ Colicin Genes } & \multirow[b]{2}{*}{ Colicin Inhibition } \\
\hline & $\begin{array}{c}\text { Type IV Pilus } \\
\text { Biogenesis Protein }\end{array}$ & Tra Genes & & $\begin{array}{c}\text { Colicin Ia } \\
\text { Synthesis Protein }\end{array}$ & Colicin Ib Protein & $\begin{array}{c}\text { Colicin V } \\
\text { Synthesis Protein }\end{array}$ & $\begin{array}{c}\text { Colicin Ib } \\
\text { Immunity Protein }\end{array}$ & \\
\hline N032 & $\mathrm{N}$ & traTJ & NO & cia & $c i b$ & $c v a A B$ & $i m m$ & YES \\
\hline N033 & $\mathrm{N}$ & traTJ & NO & cia & $c i b$ & $c v a A B$ & $i m m$ & YES \\
\hline N034 & pilJPM & traTJ & YES & cia & $c i b$ & $c v a A B$ & $i m m$ & YES \\
\hline N035 & $\mathrm{N}$ & traTJ & $\mathrm{NO}$ & cia & $c i b$ & $c v a A B$ & $i m m$ & YES \\
\hline N061 & pilJPM & traTJ & $\mathrm{NO}$ & cia & $c i b$ & $\mathrm{~N}$ & $i m m$ & NO \\
\hline N062 & piljPM & traTJ & NO & cia & $c i b$ & $\mathrm{~N}$ & $i m m$ & $\mathrm{NO}$ \\
\hline N063 & piljPM & traTJ & $\mathrm{NO}$ & cia & $c i b$ & $\mathrm{~N}$ & $i m m$ & $\mathrm{NO}$ \\
\hline N065 & pilJPM & traTJ & $\mathrm{NO}$ & cia & $c i b$ & $\mathrm{~N}$ & $i m m$ & YES \\
\hline N066 & pilJPM & traTJ & $\mathrm{NO}$ & cia & $c i b$ & $\mathrm{~N}$ & $i m m$ & $\mathrm{NO}$ \\
\hline N067 & pilJPM & traTJ & $\mathrm{NO}$ & cia & $c i b$ & $\mathrm{~N}$ & imm & NO \\
\hline N068 & pilJPM & traTJ & NO & cia & $c i b$ & $\mathrm{~N}$ & $\mathrm{imm}$ & YES \\
\hline N069 & pilJPM & traTJ & YES & cia & $c i b$ & $c v a A B C$ & $\mathrm{imm}$ & YES \\
\hline N070 & pilJPM & traTJ & $\mathrm{NO}$ & cia & $c i b$ & $\mathrm{~N}$ & imm & $\mathrm{NO}$ \\
\hline N071 & pilJPM & traTJ & $\mathrm{NO}$ & cia & $c i b$ & $\mathrm{~N}$ & $\mathrm{imm}$ & YES \\
\hline N073 & pilJPM & traTJ & $\mathrm{NO}$ & cia & $c i b$ & $\mathrm{~N}$ & $i m m$ & YES \\
\hline N075 & pilJPM & traTJ & $\mathrm{NO}$ & cia & $c i b$ & $\mathrm{~N}$ & $\mathrm{imm}$ & $\mathrm{NO}$ \\
\hline N135 & pilJPM & traTJ & $\mathrm{NO}$ & cia & $c i b$ & $c v a A B C$ & imm & YES \\
\hline N138 & pilJPM & traTJ & $\mathrm{NO}$ & cia & $c i b$ & $c v a A B C$ & imm & YES \\
\hline N140 & piljPM & traTJ & $\mathrm{NO}$ & cia & $c i b$ & $c v a A B C$ & $\mathrm{imm}$ & YES \\
\hline
\end{tabular}

$\mathrm{N}$ : indicates absence of the gene. 
Table 3. In silico genome analysis of isolates able to transfer plasmids and antimicrobial resistance genes to recipients and able to generate transconjugants.

\begin{tabular}{|c|c|c|c|c|c|}
\hline Donor & PlasmidFinder & ResFinder (Resistance Genes) & Transconjugant & PlasmidFinder & ResFinder (Resistance Genes) \\
\hline 163 & $\begin{array}{l}\text { IncFIB, IncFIA, IncA/C2, } \\
\text { IncFII(pCoo), IncX4, IncI1 }\end{array}$ & $\begin{array}{c}\text { blaCMY-2, blaTEM-1B, sul1, sul2, } \\
\text { aac(3)-VIa, aadA1, ant (2")-Ia, } \\
\text { aph(3")-Ib, aph(3')-Ia, aph(6)-Id, cmlA1, } \\
\text { floR, tet }(A), \operatorname{tet}(B)\end{array}$ & X163 & IncI1, IncX4 & sul1, aac(3)-VIa, aadA1 \\
\hline 375 & $\begin{array}{l}\text { IncFIB, ColpVC, IncA/C2, } \\
\text { IncFII(S), IncI1 }\end{array}$ & $\begin{array}{c}\text { sul1, sul2, aac(3)-VIa, aadA12, } \\
\text { aph(3")-Ib, aph(3')-Ia, aph(6)-Id, tet( } A), \\
\text { blaCMY-2, floR }\end{array}$ & X375 & IncA/C2 & $\begin{array}{l}\text { sul2, blaCMY-2, tet }(A) \\
\operatorname{aph}\left(3^{\prime \prime}\right)-I b, \operatorname{aph}(6)-I d\end{array}$ \\
\hline 393 & $\begin{array}{l}\text { IncFIB, ColpVC, IncFIA, } \\
\text { IncFII, IncI1 }\end{array}$ & $\begin{array}{c}\text { blaTEM-1B, blaTEM, aph (3')-Ia, } \\
\text { aadA12, tet }(A), \operatorname{sul1}\end{array}$ & X393 & IncFIB, IncFIA, IncFII & $\operatorname{tet}(A), \operatorname{sul} 1, \operatorname{aad} A 12, \operatorname{aph}\left(3^{\prime}\right)-I a$ \\
\hline 443 & $\begin{array}{l}\text { IncFIB, IncA/C2, } \\
\text { IncFIA, IncFII(pCoo) }\end{array}$ & $\begin{array}{l}\operatorname{ant}\left(2^{\prime \prime}\right)-I a, \operatorname{aph}\left(3^{\prime \prime}\right)-I b, \text { aph }\left(3^{\prime}\right)-I a, \\
\text { aph }(6)-I d, \text { blaCMY-2, blaTEM-1B, } \\
\text { cmlA1, floR, tet }(A), \text { tet }(B), \text { sul2 }\end{array}$ & X443 & IncFIB, IncFIA, IncFII(pcoo) & $\operatorname{aph}\left(3^{\prime \prime}\right)-I b, \operatorname{aph}\left(3^{\prime}\right)-I a, \operatorname{aph}(6)-I d, \operatorname{sul} 2$, tet $(B)$ \\
\hline 447 & $\begin{array}{l}\text { IncFIB, ColpVC, IncA/C2, } \\
\text { IncFIA, IncFII(pCoo) }\end{array}$ & $\begin{array}{l}\text { aph(3")-Ib, aph(3')-Ia, aph(6)-Id, } \\
\text { blaCMY-2, floR, tet }(A), \operatorname{tet}(B), \text { sul2 }\end{array}$ & X447 & IncFIB, IncFIA, IncFII(pcoo) & $\operatorname{tet}(B), \operatorname{sul} 2, \operatorname{aph}\left(3^{\prime \prime}\right)-I b, \operatorname{aph}\left(3^{\prime}\right)-I a, \operatorname{aph}(6)-I d$ \\
\hline 452 & $\begin{array}{l}\text { IncFIB, ColpVC, IncFIA, } \\
\text { IncFII(pCoo), IncA/C2 }\end{array}$ & $\begin{array}{l}\text { blaCMY-2, blaTEM, tet }(A), \text { tet }(B), \text { sul2, } \\
\text { ant (2")-Ia, aph (3")-Ib, aph(3")-Ib, } \\
\text { aph(3')-Ia, aph(6)-Id, cmlA1, floR }\end{array}$ & X452 & IncFIB, IncFIA, IncFII(pcoo) & $\operatorname{aph}\left(3^{\prime \prime}\right)-I b, \operatorname{aph}\left(3^{\prime}\right)-I a, \operatorname{aph}(6)-I d, \operatorname{sul} 2, \operatorname{tet}(B)$ \\
\hline 457 & $\begin{array}{l}\text { IncFIB, ColpVC, IncFIA, } \\
\text { IncFII(pCoo) }\end{array}$ & $\begin{array}{l}\text { aph(3")-Ib, aph(3')-Ia, aph(6)-Id, } \\
\text { blaCMY-2, floR, tet }(A), \operatorname{tet}(B), \text { sul2 }\end{array}$ & X457 & IncFIB, IncFIA, IncFII(pcoo) & $\operatorname{sul2,} \operatorname{aph}\left(3^{\prime \prime}\right)-I b$, tet $(B)$ \\
\hline 458 & $\begin{array}{l}\text { IncFIB, ColpVC, IncFIA, } \\
\text { IncFII, IncI1 }\end{array}$ & blaTEM-1B & X458 & IncFIB, IncFIA, IncFII & blaTEM-1B \\
\hline 459 & $\begin{array}{l}\text { IncFIB, Col156, } \\
\text { IncFIC(FII), IncI1 }\end{array}$ & blaCMY-2 & X459 & IncI1 & blaCMY-2 \\
\hline 460 & $\begin{array}{l}\text { IncFIB, ColpVC, IncA/C2, } \\
\text { IncFIA, IncFII(pCoo) }\end{array}$ & $\begin{array}{c}\text { aph(3")-Ib, aph(3')-Ia, aph(6)-Id, } \\
\text { blaCMY-2, floR, tet }(A), \text { tet }(B), \text { sul2 }\end{array}$ & X460 & IncFIB, IncFIA, IncFII(pcoo) & $\operatorname{aph}\left(3^{\prime \prime}\right)-I b, \operatorname{aph}\left(3^{\prime}\right)-I a, \operatorname{aph}(6)-I d, \operatorname{sul} 2, \operatorname{tet}(B)$ \\
\hline 462 & $\begin{array}{l}\text { IncFIB, IncA/C2, } \\
\text { IncFIA, IncFII(pCoo) }\end{array}$ & $\begin{array}{c}\text { blaCMY-2, blaTEM-1B, sul2, tet }(A), \\
\text { tet }(B), \operatorname{cml} A 1, \text { floR, ant }\left(2^{\prime \prime}\right)-I a, \\
\operatorname{aph}\left(3^{\prime \prime}\right)-I b, \operatorname{aph}\left(3^{\prime}\right)-I a, \operatorname{aph}(6)-I d\end{array}$ & $\mathrm{X} 462$ & IncFIB, IncFIA, IncFII(pcoo) & $\operatorname{sul2}, \operatorname{aph}\left(3^{\prime \prime}\right)-I b, \operatorname{aph}\left(3^{\prime}\right)-I a, \operatorname{aph}(6)-I d, \operatorname{tet}(B)$ \\
\hline 463 & $\begin{array}{l}\text { IncFIB, ColpVC, IncFII, } \\
\text { IncI1, Col156, IncFIA }\end{array}$ & $\begin{array}{l}\text { sul1, aad A12, aph }\left(3^{\prime}\right)-I a, \\
\text { tet }(A), \text { blaTEM-1B }\end{array}$ & X463 & IncFIB, IncFIA, IncFII & $\operatorname{aad} A 12, \operatorname{aph}\left(3^{\prime}\right)-\operatorname{Ia}, \operatorname{blaTEM}-1 B, \operatorname{sul} 1, \operatorname{tet}(A)$ \\
\hline
\end{tabular}


Table 3. Cont.

\begin{tabular}{|c|c|c|c|c|c|}
\hline Donor & PlasmidFinder & ResFinder (Resistance Genes) & Transconjugant & PlasmidFinder & ResFinder (Resistance Genes) \\
\hline 464 & $\begin{array}{l}\text { IncFIB, ColpVC, IncA/C2, } \\
\text { IncFIA, IncFII(pCoo) }\end{array}$ & $\begin{array}{l}\operatorname{ant}\left(2^{\prime \prime}\right)-I a, \operatorname{aph}\left(3^{\prime \prime}\right)-I b, \text { aph }\left(3^{\prime}\right)-I a, \\
\operatorname{aph}(6)-I d, \operatorname{blaCM} Y-2, \operatorname{blaTEM}-1 B, \\
\text { cmlA1, floR, tet }(A), \operatorname{tet}(B), \text { sul2 }\end{array}$ & X464 & IncFIB, IncFIA, IncFII(pcoo) & $\operatorname{aph}\left(3^{\prime \prime}\right)-I b, \operatorname{aph}\left(3^{\prime}\right)-I a, \operatorname{aph}(6)-I d, \operatorname{sul} 2$, tet $(B)$ \\
\hline 465 & $\begin{array}{c}\text { IncFIB, IncA/C2, } \\
\text { IncFIA, IncFII(pCoo) }\end{array}$ & 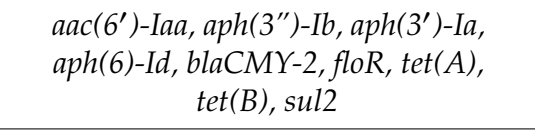 & X465 & IncFIB, IncFIA, IncFII(pcoo) & $\operatorname{aph}\left(3^{\prime \prime}\right)-I b, \operatorname{aph}\left(3^{\prime}\right)-I a, a p h(6)-I d, \operatorname{sul} 2, \operatorname{tet}(B)$ \\
\hline 477 & $\begin{array}{l}\text { IncFIB, ColpVC, IncA/C2, } \\
\text { IncFIA, IncFII (pCoo) }\end{array}$ & $\begin{array}{l}\text { aph(3")-Ib, aph(3')-Ia, aph(6)-Id, } \\
\text { blaCMY-2, floR, tet }(A), \text { tet }(B), \text { sul2 }\end{array}$ & X477 & IncFIB, IncFIA, IncFII(pcoo) & $\operatorname{aph}\left(3^{\prime \prime}\right)-I b, \operatorname{aph}\left(3^{\prime}\right)-I a, \operatorname{aph}(6)-I d$, sul2 \\
\hline 478 & $\begin{array}{c}\text { IncFIB, IncA/C2, } \\
\text { IncFIA, IncFII(pCoo) }\end{array}$ & $\begin{array}{c}\text { aadA1, aadA12, aadA21, aadA22, } \\
\text { aph(3")-Ib, aph (3')-Ia, aph(6)-Id, } \\
\text { blaCMY-2, blaTEM-1B, cmlA1, floR, } \\
\text { tet }(A), \operatorname{tet}(B), \text { sul2 }\end{array}$ & X478 & $\begin{array}{c}\text { IncFIB, IncFIA, } \\
\text { IncFII(pcoo), IncA/C2 }\end{array}$ & $\begin{array}{c}\text { cmlA1, floR, tet }(A), \text { tet }(B), \text { sul2, aph(3")-Ib, } \\
\text { aph(6)-Id, blaCMY-2, blaTEM-1B }\end{array}$ \\
\hline 485 & $\begin{array}{l}\text { IncFIB, IncA/C2, IncFIA, } \\
\text { IncFII(pCoo) }\end{array}$ & $\begin{array}{l}\operatorname{ant}\left(2^{\prime \prime}\right)-I a, \operatorname{aph}\left(3^{\prime \prime}\right)-I b, \text { aph }\left(3^{\prime}\right)-I a, \\
\text { aph(6)-Id, blaCMY-2, blaTEM-1B, } \\
\text { cmlA1, floR, tet }(A), \text { tet }(B), \text { sul2 }\end{array}$ & X485 & IncFIB, IncFIA, IncFII(pcoo) & 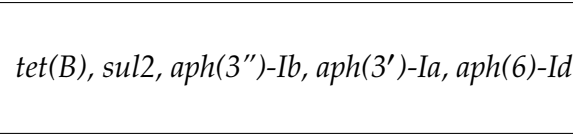 \\
\hline 486 & $\begin{array}{c}\text { IncFIB, IncA/C2, } \\
\text { IncFIA, IncFII(pCoo) }\end{array}$ & $\begin{array}{l}\operatorname{ant}\left(2^{\prime \prime}\right)-I a, \operatorname{aph}\left(3^{\prime \prime}\right)-I b, \text { aph }\left(3^{\prime}\right)-I a, \\
\text { aph(6)-Id, blaCMY-2, blaTEM-1B, } \\
\text { cmlA1, floR, tet }(A), \text { tet }(B), \text { sul2 }\end{array}$ & X486 & IncFIB, IncFIA, IncFII(pcoo)) & $\operatorname{aph}\left(3^{\prime \prime}\right)-I b, \operatorname{aph}\left(3^{\prime}\right)-I a, a p h(6)-I d, \operatorname{sul} 2, \operatorname{tet}(B)$ \\
\hline 494 & IncFIB, IncFII(S), IncA/C2 & $\begin{array}{l}\text { blaCMY-2, blaTEM-1B, sul2, sul1 } \\
\text { tet }(A), \text { floR, ant }\left(2^{\prime \prime}\right)-I a, \text { aph }\left(3^{\prime \prime}\right)-I b, \\
\text { aph(3')-Ia, aph(6)-Id }\end{array}$ & X494 & IncA/C2 & $\begin{array}{l}\text { blaCMY-2, tet }(A), \text { floR, aph(3")-Ib, } \\
\text { aph(6)-Id, sul2 }\end{array}$ \\
\hline 710 & $\begin{array}{l}\text { IncFIB, IncFIA, IncA/C2, } \\
\text { IncFII(pCoo), IncX4 }\end{array}$ & $\begin{array}{c}\text { ant (2")-Ia, aph(3")-Ib, aph(6)-Id, cmlA1, } \\
\text { floR, tet }(A), \operatorname{tet}(B), \text { sul2, } \\
\text { blaCMY-2, blaTEM-1B }\end{array}$ & X710 & IncFIB, IncFIA, IncFII(pcoo) & $\operatorname{tet}(B), \operatorname{aph}\left(3^{\prime \prime}\right)-I b, \operatorname{aph}\left(3^{\prime}\right)-I a, \operatorname{aph}(6)-I d, \operatorname{sul} 2$ \\
\hline N029 & $\begin{array}{l}\text { IncFIB, ColpVC, } \\
\text { IncFIC(FII), IncHI2, } \\
\text { IncHI2A }\end{array}$ & $\operatorname{aph}\left(3^{\prime \prime}\right)-I b, \operatorname{aph}(6)-I d$, tet $(B)$, blaCMY-2 & XN029 & IncFIB & $\operatorname{aph}\left(3^{\prime \prime}\right)-I b, a p h(6)-I d, \operatorname{tet}(B)$ \\
\hline N030 & $\begin{array}{l}\text { IncFIB, ColpVC, } \\
\text { IncFIC(FII), IncI1 }\end{array}$ & $a p h\left(3^{\prime \prime}\right)-I b, b l a C M Y-2$ & XN030 & ColpVC, IncI1 & $\operatorname{aph}\left(3^{\prime \prime}\right)-I b$, blaCMY-2 \\
\hline N034 & $\begin{array}{l}\text { IncFIB, ColpVC, } \\
\text { IncFIC(FII), IncI1 }\end{array}$ & $a p h\left(3^{\prime \prime}\right)-I b, b l a C M Y-2$ & XN034 & ColpVC, IncI1 & $\operatorname{aph}\left(3^{\prime \prime}\right)-I b, b l a C M Y-2$ \\
\hline N069 & $\begin{array}{l}\text { IncFIB, ColpVC, } \\
\text { IncFIC(FII), IncI1 }\end{array}$ & aadA1, sul1 & XN069 & IncI1 & $\operatorname{aac}(3)-V I a$, aadA1, sul1 \\
\hline
\end{tabular}


Table 4. In silico genome analysis for isolates that were able to transfer virulence genes to recipients and generate transconjugants.

\begin{tabular}{|c|c|c|c|c|c|c|c|c|c|c|c|}
\hline \multirow{2}{*}{ Donor } & \multicolumn{4}{|c|}{ Iron Acquisition Genes } & \multirow{2}{*}{$\begin{array}{l}\text { Salmonella Plasmid } \\
\text { Virulence (spv) }\end{array}$} & \multirow{2}{*}{ Transconjugant } & \multicolumn{4}{|c|}{ Iron Acquisition Genes } & \multirow{2}{*}{$\begin{array}{l}\text { Salmonella Plasmid } \\
\text { Virulence }(s p v)\end{array}$} \\
\hline & $i u c$ & iut & iro & sit & & & $i u c$ & iut & iro & sit & \\
\hline 163 & $i u c A B C D$ & iut $A$ & iroNB & sit $A$ & $\mathrm{~N}$ & X163 & $\mathrm{N}$ & $\mathrm{N}$ & $\mathrm{N}$ & $\mathrm{N}$ & $\mathrm{N}$ \\
\hline 375 & $\mathrm{~N}$ & iut $A$ & iroNB & sit $A$ & spv & X375 & $\mathrm{N}$ & $\mathrm{N}$ & $\mathrm{N}$ & $\mathrm{N}$ & $\mathrm{N}$ \\
\hline 393 & $\mathrm{~N}$ & iutA & iroNBC & sitA & $\mathrm{N}$ & X393 & $\mathrm{N}$ & iutA & $\mathrm{N}$ & $\mathrm{N}$ & $\mathrm{N}$ \\
\hline 443 & $i u c A B C D$ & iut $A$ & iroNB & sit $A B$ & $\mathrm{~N}$ & X443 & $i u c A B C D$ & iut $A$ & $\mathrm{~N}$ & sit $A B C D$ & $\mathrm{~N}$ \\
\hline 447 & $i u c A B C D$ & iut $A$ & iroNB & $\operatorname{sit} A B$ & $\mathrm{~N}$ & X447 & $i u c A B C D$ & iut $A$ & $\mathrm{~N}$ & sit $A B C D$ & $\mathrm{~N}$ \\
\hline 452 & $i u c A B C D$ & iut $A$ & iroNB & $\operatorname{sit} A B$ & $\mathrm{~N}$ & X452 & $i u c A B C D$ & iut $A$ & $\mathrm{~N}$ & sit $A B C D$ & $\mathrm{~N}$ \\
\hline 457 & $i u c A B C D$ & iut $A$ & iroNB & sit $A B$ & $\mathrm{~N}$ & X457 & $i u c A B C D$ & iut $A$ & $\mathrm{~N}$ & sit $A B C D$ & $\mathrm{~N}$ \\
\hline 458 & $\mathrm{~N}$ & iut $A$ & iroNB & sit $A$ & $\mathrm{~N}$ & X458 & $\mathrm{N}$ & iut $A$ & $\mathrm{~N}$ & $\mathrm{~N}$ & $\mathrm{~N}$ \\
\hline 459 & $i u c A B C D$ & iut $A$ & iroNBCD & sit $A B$ & $\mathrm{~N}$ & X459 & $\mathrm{N}$ & $\mathrm{N}$ & $\mathrm{N}$ & $\mathrm{N}$ & $\mathrm{N}$ \\
\hline 460 & $i u c A B C D$ & iutA & iroNB & sit $A$ & $\mathrm{~N}$ & X460 & $i u c A B C D$ & $\mathrm{~N}$ & $\mathrm{~N}$ & sit $A B C D$ & $\mathrm{~N}$ \\
\hline 462 & $i u c A B C D$ & iutA & iroNB & sit $A B$ & $\mathrm{~N}$ & X462 & $i u c A B C D$ & iut $A$ & $\mathrm{~N}$ & sit $A B C D$ & $\mathrm{~N}$ \\
\hline 463 & $\mathrm{~N}$ & iut $A$ & iroNB & sit $A$ & $\mathrm{~N}$ & X463 & $\mathrm{N}$ & iut $A$ & $\mathrm{~N}$ & $\mathrm{~N}$ & $\mathrm{~N}$ \\
\hline 464 & $i u c A B C D$ & iut $A$ & iroNB & sit $A B$ & $\mathrm{~N}$ & X464 & $i u c A B C D$ & iut $A$ & $\mathrm{~N}$ & sit $A B C D$ & $\mathrm{~N}$ \\
\hline 465 & $i u c A B C D$ & iut $A$ & iroNB & $\operatorname{sit} A B$ & $\mathrm{~N}$ & $X 465$ & $i u c A B C D$ & iut $A$ & $\mathrm{~N}$ & sit $A B C D$ & $\mathrm{~N}$ \\
\hline 477 & $i u c A B C D$ & iut $A$ & iroNB & $\operatorname{sit} A B$ & $\mathrm{~N}$ & X477 & $i u c A B C D$ & iut $A$ & $\mathrm{~N}$ & sit $A B C D$ & $\mathrm{~N}$ \\
\hline 478 & iucABCD & iut $A$ & iroNB & sit $A B$ & $\mathrm{~N}$ & X478 & iucABCD & iut $A$ & $\mathrm{~N}$ & sit $A B C D$ & $\mathrm{~N}$ \\
\hline 485 & iисABCD & iut $A$ & iroNB & sit $A B$ & $\mathrm{~N}$ & X485 & iucABCD & iut $A$ & $\mathrm{~N}$ & sit $A B C D$ & $\mathrm{~N}$ \\
\hline 486 & iucABCD & iut $A$ & iroNB & sit $A B$ & $\mathrm{~N}$ & X486 & iucABCD & iutA & $\mathrm{N}$ & sit $A B C D$ & $\mathrm{~N}$ \\
\hline 494 & $\mathrm{~N}$ & $\mathrm{~N}$ & iroNB & sitA & spv & X494 & $\mathrm{N}$ & $\mathrm{N}$ & $\mathrm{N}$ & $\mathrm{N}$ & $\mathrm{N}$ \\
\hline 710 & iucABCD & iut $A$ & iroNB & sit $A B$ & $\mathrm{~N}$ & X710 & iucABCD & iutA & $\mathrm{N}$ & sit $A B C D$ & $\mathrm{~N}$ \\
\hline N029 & $i u c A B C D$ & iut $A$ & iroNBCD & sit $A B$ & $\mathrm{~N}$ & XN029 & $i u c A C D$ & iut $A$ & $\mathrm{~N}$ & $\mathrm{~N}$ & $\mathrm{~N}$ \\
\hline N030 & iucABCD & iut $A$ & iroNBCD & sit $A B$ & $\mathrm{~N}$ & XN030 & $\mathrm{N}$ & $\mathrm{N}$ & $\mathrm{N}$ & $\mathrm{N}$ & $\mathrm{N}$ \\
\hline N034 & $i u c A B C D$ & iut $A$ & iroNBCD & sit $A B$ & $\mathrm{~N}$ & XN034 & $\mathrm{N}$ & $\mathrm{N}$ & $\mathrm{N}$ & $\mathrm{N}$ & $\mathrm{N}$ \\
\hline N069 & $i u c A B C D$ & iutA & iroNBCD & $\operatorname{sit} A B$ & $\mathrm{~N}$ & XN069 & $\mathrm{N}$ & $\mathrm{N}$ & $\mathrm{N}$ & $\mathrm{N}$ & $\mathrm{N}$ \\
\hline
\end{tabular}




\section{Discussion}

S. enterica have adopted diverse mechanisms in order to survive and proliferate within eukaryotic cells. Salmonella primarily infect the host through the consumption of contaminated animal-derived foods [1,39]. S. enterica harbors plasmids that play vital roles in the dissemination of antimicrobial resistance and virulence genes among bacteria [11]. In this study all of the $S$. Typhimurium strains carried IncFIB plasmids, one of the key features of many IncFIB plasmids is that they often possess iron acquisition genes (e.g., sit and aerobactin operons), which can play a significant role in persistence of Salmonella in the host cell, where iron is in limited supply [12]. These genes can facilitate the chelation of iron from the host during the successful infection. Additionally, IncFIB plasmids can contain antimicrobial resistance and virulence factors that have been associated with pathogenic $S$. Typhimurium [11-14,19]., which likely contribute to increase virulence of $S$. Typhimurium during infection of host cells due to carrying iron acquisition genes.

To understand the evolutionary relatedness of the IncFIB-positive S. Typhimurium strains in the current study, SNP analysis revealed the genetic structure of $S$. Typhimurium isolates clustered in three monophyletic groups based on host origin, meaning that all descendants of each host origin share the LCA, with the exception of a few isolates. Similarly, in the previous report, SNP analysis of genomes of S. enterica strains from serotypes Heidelberg, Typhimurium, and Kentucky clustered together based on the specific serotype [12]. To understand the evolutionary and temporal context of the IncFIB plasmid positive isolates in this study, it was necessary to assess the study results in the context of more recently sequenced $S$. Typhimurium isolates. We obtained eight genome sequences of more recently sequenced $S$. Typhimurium isolates from a public database. The FASTQ files were downloaded using the SRA tool kit on GalaxyTrakr and built the SNP tree incorporated with the isolates from the current study using the CFSAN SNP pipeline. The SNP based evolutionary tree showed S. Typhimurium isolate 368 that originated from cattle in 1999 was grouped in a phylogenetic clade with isolates originating from swine in 2016 and cattle in 2010 (Figure S1 green box). These isolates carrying IncFIB shared a high degree of genetic relatedness and two of these isolates carried similar antimicrobial resistance genes, including floR, bla $C A R B-2, a a d A 2 b$, sul1, and tet $(G)$, with the strain isolated in 2010 lacking AMR genes. Likewise, S. Typhimurium isolated from turkey in 2012 formed a clade with strains 463, 458, and 393 which originated from turkey and swine in 1999 (Figure S1 red box). ResFinder revealed that these isolates 463,458 , and 393 carried identical antimicrobial resistances genes, including $b l a_{T E M-1 B}, \operatorname{tet}(A)$, and sul1, while a strain isolated from turkey in 2012 carried tet $(B)$ and sul2. Also, we found that these isolates were grouped in a phylogenetic clade with those from poultry-associated strains isolated in 2005, 2011, and 2016. These strains shared the LCA, and they carried similar AMR genes, including $a p h\left(3^{\prime \prime}\right)-I b$, aph $\left(6^{\prime \prime}\right)-I d$, sul2, tet (A), and tet(B) (Figure S1 blue box). A S. Typhimurium strain isolated from turkey in 2018 branched separately from the isolates originated from turkey and cattle in 1999 (Figure S1 brown box). Also, we found that the strain from swine isolated in 1999 closely clustered with S. Typhimurium carrying the IncFIB plasmid isolated from swine in 2018. These strains demonstrated a high degree of genetic relatedness and carried the same antimicrobial resistance gene tet( $B$ ) (Figure S1 purple box). Overlapping genotypes of isolates from the late 1990s with those isolated as recently as 2018 indicate that multiple IncFIB-positive Salmonella strains have likely persisted in livestock environments over multiple decades and can potentially lead to continued problems with antimicrobial resistance.

Several studies have indicated that IncFIB plasmids likely contribute to increased colonization in the cecum of poultry, which may help explain their persistence in food animal populations [12,40]. After colonization, Salmonella can compete with other bacteria by producing antimicrobials, such as bacteriocins, which are often called colicins [41]. In the inflamed gut it was found that the pCol1B9-plasmid was able to transfer from S. Typhimurium to commensal E. coli [42]. This plasmid encodes for colicin $\mathrm{Ib}(\mathrm{cib})$ and immunity $(\mathrm{imm})$, which increase the fitness of $S$. Typhimurium in competition with commensal colicin-sensitive E. coli [42]. The structural and functional properties of colicin Ib are closely related to colicin Ia [43]. In our earlier work, IncI1 plasmid colicin-associated 
$\mathrm{cib}$ and imm were detected in different serotypes of Salmonella. When colicin genes were detected, the corresponding inhibition phenotype was observed in E. coli J53 [13]. In the current study, 21 strains $(29 \%)$ were able to inhibit growth of colicin-negative E. coli J53. The WGS analysis using the NCBI database revealed that 21 strains were positive for cia, cib, cvaBC, and imm genes, compared to other strains.

To survive at the site of infection, Salmonella obtains scarce nutrients from the host environment. One essential nutrient is iron, which is known as a cofactor for various metabolic enzymes, acts as catalyst in electron transport processes, and regulates gene expression [12,44]. S. Typhimurium is unable to use heme as an iron source [45]. However, it possesses several iron uptake systems, such as sit $A B C D$, iroBC, and iucABCD-iutA $[8,12,46]$. Previous studies indicated that these systems play a significant role in iron acquisition and facilitate survival under low iron conditions of pathogenic bacteria $[8,12,46]$. It was demonstrated that deletion of the sit system, which encoded on the chromosome, decreased the ability of $S$. Typhimurium to cause infection in the animal host [8]. The study showed that sit and aerobactin systems located on an IncFIB plasmid resulted in an increased the ability of $S$. enterica serotypes to colonize chickens [22] and an increased persistence of $S$. Typhimurium in human intestinal epithelial cells (Caco-2) [12]. A recent study found that sit A encoded on the chromosome and IncFIB plasmids were overexpressed in $S$. Typhimurium, compared to the transconjugants [20]. It was found that $\operatorname{sit} A B C D$ and iroBC genes are located on the chromosome and the IncFIB plasmid [8,12], but iucABCD-iut $A$ is usually only plasmid encoded [11,12]. In the present study we found that isolates possessed $\operatorname{sit} A B$, iroNB, and iucABCD-iut $A$ genes. Thus, the IncFIB plasmid encoded iron acquisition systems associated with biological functions, and chromosome-encoded iron acquisition systems play a significant role in chelating iron from the host to establish successful infection as previously mentioned $[8,12,20]$ (Table S1). Iron acquisition systems may be potential targets for anti-infective approaches to control the colonization and persistence with Salmonella and other pathogens [47].

S. Typhimurium harbors Salmonella pathogenicity island-1 (SPI-1) encoded type III secretion system (T3SS) and Salmonella pathogenicity island -2 (SPI-2) encoded T3SS, which facilitate attachment, invasion, and internalization of the cells [48]. In the present study, WGS using NCTR and PATRIC databases confirmed that all isolates contained SPI-1 and SPI-2 encoded on T3SS (Table S1). Salmonella mainly depends on gene products encoded on SPI-1 to invade cells. Among them are Salmonella invasive proteins (Sips) and Salmonella outer proteins (Sops), which play a significant role in altering the actin cytoskeleton of the cell and promoting the Salmonella-containing vacuole (SCV) [49]. Within the SCV, Salmonella expresses genes encoded on SPI-2 whose proteins are important for survival and proliferation in epithelial cells [50]. Moreover, it was reported that $S$. Typhimurium is known to proliferate to large numbers in the cytosol of epithelial cells at later stages of infection [51]. Here, we used Caco-2 cells, which are derived from human intestinal epithelial cells [52]. We observed a significant increase of some persistent bacterial cells $(n=10,27 \%)$ at $48 \mathrm{~h}$, compared to invasion of the bacterial cells $(n=2$, $5 \%$ ) of $S$. Typhimurium, which is consistent with a previous study showing a significant increase in persistent cell counts after $48 \mathrm{~h}$, compared to invasion cell counts after $1 \mathrm{~h}$ of IncI1 positive Salmonella of different serotypes [14]. Furthermore, it was reported that sif $A$ and SPI-2 are involved in maintenance of the vacuolar membrane and intracellular replication in vivo [53]. Another study found that Salmonella deficient for the gene sifA cannot maintain vacuolar integrity and subsequently replicate in the cytosol of epithelial cells [54]. In this study, WGS analyses using the PATRIC and NCTR Virulence Factor database revealed that all isolates harbored the gene sifA, and SPIs encoded T3SS (Table S1).

Horizontal gene transfer (HGT) can occur between Salmonella and members of Enterobacteriaceae via conjugation, in which a recipient cell receives genetic elements from a donor cell by cell-to-cell contact through conjugative pili [16]. In the present study, most isolates of $S$. Typhimurium were positive for traJT and pilJPM genes, which are representative genes associated with the conjugal transfer function. Twenty-four isolates generated transconjugants when mated with the recipient $E$. coli J53. We found that most transconjugants harbored IncFIB plasmids along with multiple other plasmid replicon types and carried multiple antimicrobial resistance genes that were transferred from the donor. 
Some of plasmids were not transferable to E. coli J53 and this could be due to plasmid size, the sources of animal foods, mutations in pil, tra or regulatory genes and/or conjugation method employed that can impact efficiency (broth versus solid mating, incubation temperature, and donor/recipient ratio). The stability of IncFIB plasmids in bacteria is due in large part to host addiction genes, including $c c d A$, relB, and vagC $[23,24]$. Thus, the IncFIB plasmids were able to disseminate horizontally among bacteria and were maintained in bacterial populations [12]. An earlier study demonstrated that in vivo transfer of an IncFIB plasmid containing a class 1 integron harboring gene cassettes $d f r A 1$-aadA1 occurred from Salmonella to E. coli [55]. Salmonella was able to transfer multiple resistance genes on transferable plasmids to commensal $E$. coli in an in vivo assay $[56,57]$. Likewise, in an in vitro test, an IncI1 plasmid carrying tet $A, b l a C_{C M Y}, a a c C, a a d A 1$, and sul1 was shown to be conjugatively transferred from Salmonella to E. coli J53 [13].

The WGS analysis using ResFinder revealed several antimicrobial resistance genes, which corresponded to the predicted resistance phenotype in most strains. Some of the more common resistance genes identified in the IncFIB-positive isolates included $b l a_{C M Y-2}, b l a_{T E M-1 B}$, sul, aac(3)-VIa, ant (2")-Ia, aadA1, aph(3")-Ib, aph(6)-Id, aph(3')-Ia, cmlA1, floR, and tet. These genes encode resistance to AMC, AMP, TIO, SUL, GEN, STR, KAN, CHL, and TET. When the resistance phenotypes were compared to several of the genes noted, there was a positive concordance of gene presence and resistance phenotype in several strains, with few observed exceptions. However, nine strains were positive for $b l a_{T E M-1 B}$ and two were positive for $b l a_{C M Y-2}$ but were still susceptible or intermediate susceptible to AMC. Also, we found five strains $(7 \%)$ that were positive for $b l a_{C M Y-2}$ genes; however, they were still susceptible or intermediately susceptible to TIO. In a small number of cases, susceptible bacteria to AMP, CHL GEN, and SUL were positive for $\operatorname{bla}_{T E M-1 B}(n=1,1.4 \%)$, floR $(n=1,1.4 \%)$, ant $(2 ")$-la $(n=1$, $1.4 \%)$, aac (3)-Via $(n=1,1.4 \%)$ and $\operatorname{sul}(n=1,1.4 \%)$, respectively. This study is consistent with a previous study that found some susceptible strains to TET and SUL were positive for tet $A$ and sul1 genes on IncI plasmid-positive Salmonella [13]. The difference between genotype and phenotype in these strains might be due to mutations that reduce the expression of genes. Thus, point mutations in genes can confer susceptibility to selected antimicrobial agents. Despite the discovery of many antimicrobial resistance genes and genetic transfer mechanisms, the non-genetic mechanisms mediated by small molecules can alter the antibiotic susceptibility of bacteria cells [58]. Indole, which is produced by Gram-positive and Gram-negative bacteria, can also protect the bacterial cells from antibiotic damage [59]. It was found that certain E. coli produce a higher level of indole in the presence of ampicillin and kanamycin [59]. Furthermore, indole can mediate upregulation of multidrug efflux pumps by inducing the expression of various multidrug genes and enhancing the efflux of antibiotics [60,61]. Efflux pumps allow bacteria to regulate their internal environment by removing toxic materials, including antimicrobial agents [62]. In the present study we found that some strains were resistant to SUL $(n=9,16 \%)$, followed by CHL $(n=8,15 \%)$, TET $(n=6,11 \%)$, STR $(n=5,9 \%), \operatorname{KAN}(n=2,3 \%)$ AMC $(n=1,2 \%)$, AMP $(n=1,2 \%)$, TIO $(n=1,2 \%)$, and GEN $(n=1,2 \%)$, and yet did not have a corresponding resistance gene detected. Resistance of these strains could be due to the intrinsic resistance of antibiotic response as previously suggested [60-62]. In the WGS data from the eight reference strains analyzed, ResFinder revealed that these strains possessed resistance genes similar to those detected in strains from the study including aadA12, aadA2, aph(3')-Ia, blaTEM-1B, sul1, sul2, tet $(A), \operatorname{tet}(B), \operatorname{tet}(G), \operatorname{aph}\left(3^{\prime \prime}\right)-I b, \operatorname{aph}(6)-I d, \operatorname{blaCMY}-2$ and floR (Table S2).

\section{Conclusions}

Salmonella is a potentially invasive pathogen that causes many human illnesses. During infection, Salmonella induces several virulence genes required to survive and compete with other bacteria. Many of these genes are encoded on transferable plasmids, which can facilitate the horizontal transfer of virulence genes, along with multiple antimicrobial resistance genes. The IncFIB plasmids, which often carry multiple resistance determinants and virulence factors, were detected in $S$. Typhimurium. This study was undertaken to assess the genomic and phenotypic characterization of IncFIB positive 
S. Typhimurium isolates from different animal-derived foods. Results of this study showed that IncFIB plasmids along with other plasmid replicon types can contribute to antimicrobial resistance, virulence factors, and persistence in intestinal epithelial cells. Thus, IncFIB plasmids represent a likely threat to human and animal health due to the transfer of antimicrobial resistance and virulence genes to susceptible bacteria. WGS-based sequence analyses associated with phenotype analysis of IncFIB plasmids facilitate better understanding of the genetics of antimicrobial resistance and virulence genes, which will help in the design of specific intervention strategies to stop plasmid spread among bacteria.

Supplementary Materials: The following are available online at http://www.mdpi.com/2073-4425/11/11/1307/s1, Figure S1: SNP-based phylogenetic tree analysis for 79 S. Typhimurium. The isolate number/names are followed by the year of isolation, Table S1: Iron acquisition system genes and SPI-1 and SPI-2 encoded T3SS genes found in the 71 S. Typhimurium isolates using PATRIC, Table S2: Additional reference S. Typhimurium isolates including their plasmid types and antimicrobial resistance genes of the more recently sequenced, Table S3: Spreadsheet displaying the results of the NCTR Virulence Factor Database gene detection for the S. Typhimurium isolates included in the study.

Author Contributions: S.L.F. and R.N. secured the funds for the project. S.L.F., N.H.A., J.H., R.S., J.G., B.K.K. and Y.M.S. designed the studies. N.H.A., J.H., Y.M.S., J.D., K.W., and J.C. conducted the laboratory studies. S.L.F., N.H.A., B.K.K., Y.M.S., J.H., and R.N. conducted the data analysis. N.H.A. and S.L.F. wrote the final manuscript. All contributed to the editing and refinement of the finished manuscript. All authors have read and agreed to the published version of the manuscript.

Funding: All of the funding for the project was internal FDA funding.

Acknowledgments: The authors would like to recognize Ashraf Khan, Mohamed Nawaz and Carl Cerniglia for their critical review of the manuscript. This research was supported by the National Center for Toxicological Research and U.S. Food and Drug Administration. Nesreen Aljahdali was supported in part by an appointment to the Research Participation Program at the National Center for Toxicological Research administered by the Oak Ridge Institute for Science and Education (ORISE) through an interagency agreement between the U.S. Department of Energy and the U.S. Food and Drug Administration. The opinions expressed in this manuscript are solely the responsibility of the authors and do not necessarily represent the official views and policy of the Food and Drug Administration or Department of Health and Human Services.

Conflicts of Interest: The authors declare no conflict of interest.

Data Availability: All sequences generated for this project can be found in GenBank, under the accession numbers listed in Table 1.

\section{References}

1. Scallan, E.; Hoekstra, R.M.; Angulo, F.J.; Tauxe, R.V.; Widdowson, M.A.; Roy, S.L.; Jones, J.L.; Griffin, P.M. Foodborne illness acquired in the united states-major pathogens. Emerg. Infect. Dis. 2011, 17, 7-15. [CrossRef] [PubMed]

2. CDC. National Enteric Disease Surveillance Salmonella Annual Report. Available online: https://www.cdc. gov/salmonella/index.html (accessed on 5 March 2020).

3. USDA. Cost Estimates of Foodborne Illnesses, Cost of Foodborne Illness Estimates for Salmonella (Non-typhoidal). Available online: https://www.ers.usda.gov/data-products/cost-estimates-of-foodborneillnesses.aspx\#48498 (accessed on 15 June 2020).

4. Hoffman, S.; Maculloch, B.; Batz, M. Economic burden of major foodborne illnesses acquired in the United States. Econ. Res. Serv. 2015. [CrossRef]

5. Foley, S.L.; Johnson, T.J.; Ricke, S.C.; Nayak, R.; Danzeisen, J. Salmonella pathogenicity and host adaptation in chicken-associated serovars. Microbiol. Mol. Biol. Rev. 2013, 77, 582-607. [CrossRef] [PubMed]

6. CDC. National Salmonella Surveillance. Available online: https://www.cdc.gov/nationalsurveillance/ salmonella-surveillance.html (accessed on 23 May 2019).

7. CDC. An Altas of Salmonella in the United States, 1968-2011. Available online: https://www.cdc.gov/ salmonella/pdf/salmonella-atlas-508c.pdf (accessed on 27 June 2019).

8. Janakiraman, A.; Slauch, J.M. The putative iron transport system sitabcd encoded on spi1 is required for full virulence of salmonella typhimurium. Mol. Microbiol. 2000, 35, 1146-1155. [CrossRef] [PubMed]

9. Winnen, B.; Schlumberger, M.C.; Sturm, A.; Schupbach, K.; Siebenmann, S.; Jenny, P.; Hardt, W.D. Hierarchical effector protein transport by the salmonella typhimurium spi-1 type iii secretion system. PLoS ONE 2008, 3, e2178. [CrossRef] 
10. Sabbagh, S.C.; Forest, C.G.; Lepage, C.; Leclerc, J.M.; Daigle, F. So similar, yet so different: Uncovering distinctive features in the genomes of salmonella enterica serovars typhimurium and typhi. FEMS Microbiol. Lett. 2010, 305, 1-13. [CrossRef] [PubMed]

11. Han, J.; Lynne, A.M.; David, D.E.; Tang, H.L.; Xu, J.S.; Nayak, R.; Kaldhone, P.; Logue, C.M.; Foley, S.L. DNA sequence analysis of plasmids from multidrug resistant salmonella enterica serotype heidelberg isolates. PLOS ONE 2012, 7, e51160. [CrossRef] [PubMed]

12. Khajanchi, B.K.; Hasan, N.A.; Choi, S.Y.; Han, J.; Zhao, S.H.; Colwell, R.R.; Cerniglia, C.E.; Foley, S.L. Comparative genomic analysis and characterization of incompatibility group fib plasmid encoded virulence factors of salmonella enterica isolated from food sources. BMC Genom. 2017, 18, 14. [CrossRef]

13. Kaldhone, P.R.; Han, J.; Deck, J.; Khajanchi, B.; Nayak, R.; Foley, S.L.; Ricke, S.C. Evaluation of the genetics and functionality of plasmids in incompatibility group i1-positive salmonella enterica. Foodborne Pathog. Dis. 2018, 15, 168-176. [CrossRef]

14. Kaldhone, P.R.; Carlton, A.; Aljahdali, N.; Khajanchi, B.K.; Sanad, Y.M.; Han, J.; Deck, J.; Ricke, S.C.; Foley, S.L. Evaluation of incompatibility group i1 (inci1) plasmid-containing salmonella enterica and assessment of the plasmids in bacteriocin production and biofilm development. Front. Vet. Sci. 2019, 6, 298. [CrossRef]

15. Jakociune, D.; Bisgaard, M.; Pedersen, K.; Olsen, J.E. Demonstration of persistent contamination of a cooked egg product production facility with salmonella enterica serovar Tennessee and characterization of the persistent strain. J. Appl. Microbiol. 2014, 117, 547-553. [CrossRef] [PubMed]

16. Szmolka, A.; Nagy, B. Multidrug resistant cornmensal escherichia coli in animals and its impact for public health. Front. Microbiol. 2013, 4, 13. [CrossRef] [PubMed]

17. Sanad, Y.M.; Johnson, K.; Park, S.H.; Han, J.; Deck, J.; Foley, S.L.; Kenney, B.; Ricke, S.; Nayak, R. Molecular characterization of salmonella enterica serovars isolated from a turkey production facility in the absence of selective antimicrobial pressure. Foodborne Pathog. Dis. 2016, 13, 80-87. [CrossRef]

18. Aljahdali, N.H.; Kaldhone, P.R.; Foley, S.L.; Khajanchi, B.K. Whole-genome sequences of 35 incompatibility group i1 plasmid-carrying salmonella enterica isolates from food animal and clinical sources. Microbiol. Resour. Announc. 2019, 8, e00831-19. [CrossRef] [PubMed]

19. Aljahdali, N.H.; Foley, S.L.; Han, J.; Sanad, Y.M.; Nayak, R.; Khajanchi, B.K. Whole-genome sequences of 66 incompatibility group fib plasmid-carrying salmonella enterica serovar typhimurium isolates from food animal sources. Microbiol. Resour. Announc. 2020, 9. [CrossRef]

20. Khajanchi, B.K.; Xu, J.; Grim, C.J.; Ottesen, A.R.; Ramachandran, P.; Foley, S.L. Global transcriptomic analyses of salmonella enterica in iron-depleted and iron-rich growth conditions. BMC Genom. 2019, 20, 490. [CrossRef] [PubMed]

21. Porcheron, G.; Dozois, C.M. Interplay between iron homeostasis and virulence: Fur and ryhb as major regulators of bacterial pathogenicity. Vet. Microbiol. 2015, 179, 2-14. [CrossRef]

22. Johnson, T.J.; Thorsness, J.L.; Anderson, C.P.; Lynne, A.M.; Foley, S.L.; Han, J.; Fricke, W.F.; McDermott, P.F.; White, D.G.; Khatri, M.; et al. Horizontal gene transfer of a colv plasmid has resulted in a dominant avian clonal type of salmonella enterica serovar kentucky. PLOS ONE 2010, 5, e15524. [CrossRef]

23. Mnif, B.; Vimont, S.; Boyd, A.; Bourit, E.; Picard, B.; Branger, C.; Denamur, E.; Arlet, G. Molecular characterization of addiction systems of plasmids encoding extended-spectrum $\beta$-lactamases in escherichia coli. J. Antimicrob. Chemother. 2010, 65, 1599-1603. [CrossRef]

24. Mnif, B.; Harhour, H.; Jdidi, J.; Mahjoubi, F.; Genel, N.; Arlet, G.; Hammami, A. Molecular epidemiology of extended-spectrum $\beta$-lactamase-producing escherichia coli in tunisia and characterization of their virulence factors and plasmid addiction systems. BMC Microbiol. 2013, 13, 147. [CrossRef]

25. Johnson, T.J.; Johnson, S.J.; Nolan, L.K. Complete DNA sequence of a colbm plasmid from avian pathogenic escherichia coli suggests that it evolved from closely related colv virulence plasmids. J. Bacteriol. 2006, 188, 5975-5983. [CrossRef]

26. Jacoby, G.A.; Han, P. Detection of extended-spectrum $\beta$-lactamases in clinical isolates of klebsiella pneumoniae and escherichia coli. J. Clin. Microbial. 1996, 34, 908-911. [CrossRef]

27. Foley, S.L.; White, D.G.; McDermott, P.F.; Walker, R.D.; Rhodes, B.; Fedorka-Cray, P.J.; Simjee, S.; Zhao, S.H. Comparison of subtyping methods for differentiating salmonella enterica serovar typhimurium isolates obtained from food animal sources. J. Clin. Microbial. 2006, 44, 3569-3577. [CrossRef] 
28. Kaldhone, P.; Nayak, R.; Lynne, A.M.; David, D.E.; McDermott, P.F.; Logue, C.M.; Foley, S.L. Characterization of salmonella enterica serovar heidelberg from turkey-associated sources. Appl. Environ. Microbiol. 2008, 74, 5038-5046. [CrossRef]

29. Lynne, A.M.; Dorsey, L.L.; David, D.E.; Foley, S.L. Characterisation of antibiotic resistance in host-adapted salmonella enterica. Int. J. Antimicrob. Agents 2009, 34, 169-172. [CrossRef]

30. Lynne, A.M.; Rhodes-Clark, B.S.; Bliven, K.; Zhao, S.H.; Foley, S.L. Antimicrobial resistance genes associated with salmonella enterica serovar newport isolates from food animals. Antimicrob. Agents Chemother. 2008, 52, 353-356. [CrossRef]

31. Gokulan, K.; Khare, S.; Rooney, A.W.; Han, J.; Lynne, A.M.; Foley, S.L. Impact of plasmids, including those encodingvirb4/d4 type iv secretion systems, on salmonella enterica serovar heidelberg virulence in macrophages and epithelial cells. PLoS ONE 2013, 8, e77866. [CrossRef]

32. Welch, T.J.; Fricke, W.F.; McDermott, P.F.; White, D.G.; Rosso, M.L.; Rasko, D.A.; Mammel, M.K.; Eppinger, M.; Rosovitz, M.J.; Wagner, D.; et al. Multiple antimicrobial resistance in plague: An emerging public health risk. PLoS ONE 2007, 2, e309. [CrossRef] [PubMed]

33. Davis, S.; Pettengill, J.; Lou, Y.; Payne, J.; Shpuntoff, A.; Rand, H.; Strain, E. Cfsan snp pipeline: An automated method for constructing snp matrices from next-generation sequence data. PeerJ Comput. Sci. 2015, 1, e20. [CrossRef]

34. Afgan, E.; Baker, D.; Batut, B.; van den Beek, M.; Bouvier, D.; Cech, M.; Chilton, J.; Clements, D.; Coraor, N.; Gruning, B.A.; et al. The galaxy platform for accessible, reproducible and collaborative biomedical analyses: 2018 update. Nucleic Acids Res. 2018, 46, W537-W544. [CrossRef]

35. Stamatakis, A. Raxml version 8: A tool for phylogenetic analysis and post-analysis of large phylogenies. Bioinformatics 2014, 30, 1312-1313. [CrossRef]

36. Carattoli, A.; Zankari, E.; Garcia-Fernandez, A.; Larsen, M.V.; Lund, O.; Villa, L.; Aarestrup, F.M.; Hasman, H. In silico detection and typing of plasmids using plasmidfinder and plasmid multilocus sequence typing. Antimicrob. Agents Chemother. 2014, 58, 3895-3903. [CrossRef]

37. Zankari, E.; Hasman, H.; Cosentino, S.; Vestergaard, M.; Rasmussen, S.; Lund, O.; Aarestrup, F.M.; Larsen, M.V. Identification of acquired antimicrobial resistance genes. J. Antimicrob. Chemother. 2012, 67, 2640-2644. [CrossRef]

38. Wattam, A.R.; Abraham, D.; Dalay, O.; Disz, T.L.; Driscoll, T.; Gabbard, J.L.; Gillespie, J.J.; Gough, R.; Hix, D.; Kenyon, R.; et al. Patric, the bacterial bioinformatics database and analysis resource. Nucleic Acids Res. 2014, 42, D581-D591. [CrossRef]

39. Foley, S.L.; Lynne, A.M. Food animal-associated salmonella challenges: Pathogenicity and antimicrobial resistance. J. Anim. Sci. 2008, 86, E173-E187. [CrossRef] [PubMed]

40. Jacobsen, L.; Wilcks, A.; Hammer, K.; Huys, G.; Gevers, D.; Andersen, S.R. Horizontal transfer of tet(m) and erm(b) resistance plasmids from food strains of lactobacillus plantarum to enterococcus faecalis jh2-2 in the gastrointestinal tract of gnotobiotic rats. FEMS Microbiol. Ecol. 2007, 59, 158-166. [CrossRef]

41. Nedialkova, L.P.; Denzler, R.; Koeppel, M.B.; Diehl, M.; Ring, D.; Wille, T.; Gerlach, R.G.; Stecher, B. Inflammation fuels colicin ib-dependent competition of salmonella serovar typhimurium and e. Coli in enterobacterial blooms. PLoS Pathog. 2014, 10, 15. [CrossRef] [PubMed]

42. Stecher, B.; Denzler, R.; Maier, L.; Bernet, F.; Sanders, M.J.; Pickard, D.J.; Barthel, M.; Westendorf, A.M.; Krogfelt, K.A.; Walker, A.W.; et al. Gut inflammation can boost horizontal gene transfer between pathogenic and commensal enterobacteriaceae. Proc. Natl. Acad. Sci. USA 2012, 109, 1269-1274. [CrossRef]

43. Konisky, J. Characterization of colicin ia and colicin ib-Chemical studies of protein structure. J. Biol. Chem. 1972, 247, 3750-3755.

44. Ernst, F.D.; Bereswill, S.; Waidner, B.; Stoof, J.; Mader, U.; Kusters, J.G.; Kuipers, E.J.; Kist, M.; van Vliet, A.H.M.; Homuth, G. Transcriptional profiling of helicobacter pylori fur- and iron-regulated gene expression. Microbiolog 2005, 151, 533-546. [CrossRef] [PubMed]

45. Reissbrodt, R.; Kingsley, R.; Rabsch, W.; Beer, W.; Roberts, M.; Williams, P.H. Iron-regulated excretion of $\alpha$-keto acids by salmonella typhimurium. J. Bacteriol. 1997, 179, 4538-4544. [CrossRef]

46. Baumler, A.J.; Tsolis, R.M.; vanderVelden, A.W.M.; Stojiljkovic, I.; Anic, S.; Heffron, F. Identification of a new iron regulated locus of salmonella typhi. Gene 1996, 183, 207-213. [CrossRef] 
47. Marchetti, M.; Bei, O.D.; Bettati, S.; Campanini, B.; Kovachka, S.; Gianquinto, E.; Spyrakis, F.; Ronda, L. Iron Metabolism at the Interface between Host and Pathogen: From Nutritional Immunity to Antibacterial Development. Int. J. Mol. Sci. 2020, 21, 2145. [CrossRef] [PubMed]

48. Lostroh, C.P.; Lee, C.A. The salmonella pathogenicity island-1 type iii secretion system. Microb. Infect. 2001, 3, 1281-1291. [CrossRef]

49. Knodler, L.A.; Nair, V.; Steele-Mortimer, O. Quantitative assessment of cytosolic salmonella in epithelial cells. PLOS ONE 2014, 9, e84681. [CrossRef]

50. Zhang, K.Y.; Griffiths, G.; Repnik, U.; Hornef, M. Seeing is understanding: Salmonella's way to penetrate the intestinal epithelium. Int. J. Med. Microbiol. 2018, 308, 97-106. [CrossRef]

51. Knodler, L.A.; Vallance, B.A.; Celli, J.; Winfree, S.; Hansen, B.; Montero, M.; Steele-Mortimer, O. Dissemination of invasive salmonella via bacterial-induced extrusion of mucosal epithelia. Proc. Natl. Acad. Sci. USA 2010, 107, 17733-17738. [CrossRef]

52. Wrande, M.; Andrews-Polymenis, H.; Twedt, D.J.; Steele-Mortimer, O.; Porwollik, S.; McClelland, M.; Knodler, L.A. Genetic determinants of salmonella enterica serovar typhimurium proliferation in the cytosol of epithelial cells. Infect. Immun. 2016, 84, 3517-3526. [CrossRef] [PubMed]

53. Salcedo, S.P.; Noursadeghi, M.; Cohen, J.; Holden, D.W. Intracellular replication of salmonella typhimurium strains in specific subsets of splenic macrophages in vivo. Cell Microbiol. 2001, 3, 587-597. [CrossRef]

54. Beuzon, C.R.; Salcedo, S.P.; Holden, D.W. Growth and killing of a salmonella enterica serovar typhimurium sifa mutant strain in the cytosol of different host cell lines. Microbiology 2002, 148, 2705-2715. [CrossRef]

55. Van Essen-Zandbergen, A.; Smith, H.; Veldman, K.; Mevius, D. In vivo transfer of an incfib plasmid harbouring a class 1 integron with gene cassettes dfra1-aada1. Vet. Microbiol. 2009, 137, 402-407. [CrossRef]

56. Card, R.M.; Cawthraw, S.A.; Nunez-Garcia, J.; Ellis, R.J.; Kay, G.; Pallen, M.J.; Woodward, M.J.; Anjum, M.F. An in vitro chicken gut model demonstrates transfer of a multidrug resistance plasmid from salmonella to commensal escherichia coli. mBio 2017, 8, 15. [CrossRef]

57. Faure, S.; Perrin-Guyomard, A.; Delmas, J.M.; Laurentie, M. Impact of therapeutic treatment with $\beta$-lactam on transfer of the bla(ctx-m-9) resistance gene from salmonella enterica serovar virchow to escherichia coli in gnotobiotic rats. Appl. Environ. Microbiol. 2009, 75, 5523-5528. [CrossRef]

58. El-Halfawy, O.M.; Valvano, M.A. Non-genetic mechanisms communicating antibiotic resistance: Rethinking strategies for antimicrobial drug design. Expert Opin. Drug Discov. 2012, 7, 923-933. [CrossRef] [PubMed]

59. Han, T.H.; Lee, J.H.; Cho, M.H.; Wood, T.K.; Lee, J. Environmental factors affecting indole production in escherichia coli. Res. Microbiol. 2011, 162, 108-116. [CrossRef]

60. Hirakawa, H.; Inazumi, Y.; Masaki, T.; Hirata, T.; Yamaguchi, A. Indole induces the expression of multidrug exporter genes in escherichia coli. Mol. Microbiol. 2005, 55, 1113-1126. [CrossRef] [PubMed]

61. Lee, H.H.; Molla, M.N.; Cantor, C.R.; Collins, J.J. Bacterial charity work leads to population-wide resistance. Nature 2010, 467, 82-85. [CrossRef]

62. Nikaido, H. Preventing drug access to targets: Cell surface permeability barriers and active efflux in bacteria. Semin. Cell Dev. Biol. 2001, 12, 215-223. [CrossRef]

Publisher's Note: MDPI stays neutral with regard to jurisdictional claims in published maps and institutional affiliations.

(C) 2020 by the authors. Licensee MDPI, Basel, Switzerland. This article is an open access article distributed under the terms and conditions of the Creative Commons Attribution (CC BY) license (http://creativecommons.org/licenses/by/4.0/). 